Pecvnia, 3 (2006), pp. 45-94

\title{
Métodos didácticos y sistemas de aprendizaje: Teneduría de Libros y Partida Doble en Inglaterra (siglos XVI-XIX)
}

\author{
J. Lanero Fernández \\ E. Ortega Montes
}

\begin{abstract}
El presente trabajo realiza una revisión bibliográfica de los tratados pedagógicos de teneduría de libros en el Reino Unido desde el siglo XVI, cuando se incorporó la partida doble, hasta finales del siglo XIX.

Los rasgos didácticos más significativos de los primeros 250 años de docencia en teneduría de libros se resumen en la importancia que se concede al Libro Diario. Con el desarrollo de la partida doble se hizo habitual ampliar el significado de los términos débito y crédito más allá de la connotación personal original y aplicarlos a objetos inanimados y conceptos abstractos. La exposición mediante la personificación de cuentas consistía en un aprendizaje memorístico apoyado en normas y versificación.

La disputa entre los que eran partidarios del Diario y aquellos que preferían el Mayor como libro de enseñanza, no era otra cosa más que la traducción del conflicto entre el enfoque memorístico y el racional de la teneduría de
\end{abstract}

The present paper makes a bibliographic checking of the pedagogic treatises of bookkeeping in the United Kingdom since 16th Century, when the double-entry system was introduced, up to the end of 19th Century.

The most outstanding didactic feature of the first 250 years of bookkeeping teaching could be summed up in the prevalent role the Journal was given. With the development of the doubleentry system, it became common extending the meaning of the terms debit and credit beyond the original personal connotation and applying them to inanimate objects and abstract concepts. The exposition by means of accounts personification involved a system based mainly on rote-learning supported by rules and versification.

The dispute between those in favour of the Journal and the ones who preferred the Ledger as the teaching book was nothing but the translation of the conflict between the rotelearning approach and the rational one of 
libros. Los seguidores del enfoque del Mayor salieron doblemente reforzados: significaba una enseñanza más racional y un cambio en las exigencias de los negocios.

El Diario perdió su posición dominante cuando, a mediados del siglo XIX, surgió una teoría alternativa a la personificación de las cuentas. Se trata de la teoría de la propiedad de las cuentas y se ocupa del significado de éstas desde el punto de vista del propietario.

Palabras clave: Libro Diario, Libro Mayor, Teoría de la Personificación de las cuentas, Teoría de la propiedad de las cuentas. bookkeeping. Those who followed the Ledger approach came out doubly reinforced: it meant a more rational teaching and a change in business demands.

The Journal lost its prevailing position when, towards the middle of 19th Century, an alternative theory to accounts personification emerged. This is the accounts ownership theory and it deals with the meaning of accounts from the owner's point of view.

Key words: Journal, Ledger, Accounts Personification Theory, Accounts Ownership Theory.

La inmensa mayoría de autores de tratados sobre teneduría de libros, de los siglos XVI y XVII, ejercían la docencia de la materia. El método de exposición que eligieron estuvo influido por la actitud contemporánea para enseñar las disciplinas académicas y la teoría contable que de forma consciente o inconsciente sostenían cada uno de ellos.

El Libro Diario era la piedra angular del sistema italiano de cuentas, compuesto por tres libros. El objetivo primordial de la enseñanza de teneduría de libros era la debida ordenación del Debe y el Haber en ese libro. Una anotación en el diario era algo que debía realizarse

... in a strict Form, and with all the Consideration and Discretion imaginable; and it will not be done hastily, unless it be a very plain Matter; but requires the solitude of a Compting-House, or Retirement from all manner of interruption ${ }^{1}$.

La historia de la enseñanza de la teneduría de libros hasta, en la práctica, finales del siglo XIX, es la evolución de la metodología utilizada para explicar cómo averiguar qué cuentas son de cargo y de abono y cómo debe realizarse la anotación en el Libro Diario.

1 [Roger North], The Gentleman Accomptant: or An Essay to Unfold the Mistery of Accompts. By Way of Debtor and Creditor, Commonly Called Merchants Accompts, and Applying the Same to the Concerns of the Nobility and Gentry of England.... Done by a Person of Honour..., London: Printed for E. Curll, at the Dial and Bible against St. Dunstan's Church in Fleetstreet, 1714, p. 33. 
El método habitual que siguieron los manuales hasta el siglo XVIII fue el de presentar gran cantidad de reglas aplicables a casos concretos de las más variadas operaciones. Sorprendentemente, la excepción más destacable la encontramos en el primer tratado inglés sobre teneduría de libros, obra de Hugh Oldcastle, que ha llegado hasta nosotros por la reedición de John Mellis, en 1588. La versión original, de la que no se conservan ejemplares, se publicó en $1543^{2}$. Según Oldcastle/Mellis, cada anotación en el Diario posee

... two denominations: to wit, by Debitor, and Creditor, whereof the first is the name of Debitor, reciuer or borrower: and the other of the Creditor, deliuerer, lender. To the furtherance whereof there is a Rule, which beeing well understood, will aide you greatly: which Rule is to bee learned as well by rote, as by reason, which is thus.

\section{All thinges receiued, or the receiver must owe to all thinges deliuered, or to the deliuerer ${ }^{3}$.}

No se efectuó ninguna mejora de esta regla en los dos siglos siguientes. El Profesor P. Kats, en 1926, al percatarse de que esta norma no se encuentra en el tratado de Pacioli, del que el de Oldcastle es una traducción, opina que corresponde al primer tratado de Peele, publicado en $1553^{4}$. La aportación de Peele está más en consonancia con el resto de autores de los siglos XVII y XVIII. El método de Peele consiste en dar un ejemplo de transacción (cuarenta y cuatro en total), al que sigue su correspondiente anotación en el Diario, referenciándola en el resto de libros. Veamos tres ejemplos:

c Money reciued of a debitour. You shall make the money reciued, debitour to the man that did pay it, as in the 37. parcell.

2 Véase Juan Lanero Fernández, El esplendor de la teneduría de libros: la partida doble en los tratados contables ingleses de la dinastía Tudor (1543-1588), Tesis Doctoral, Universidad de León, 2004.

3 John Mellis, A Briefe Instruction and maner how to keepe bookes of Accomptes after the order of Debitor and Creditor, \& as well for proper Accompts partible, \& c. ... Imprinted at London by lohn Windet, dwelling at the Signe of the White Beare, nigh Baynards Castle, 1588, capítulo IX. 1926), pp. 483-487.

P. Kats, "Hugh Oldcastle and John Mellis," The Accountant, LXXIV (27 March 
C Money paied to the Creditour.

You shall make contrariwise the man debitour

to the money paied to hym, as in the. 38. parcell.

$\mathbb{C}$ To deliuer a Debitours bill to a Creditour.

You shall make the man that reciueth the bill, debitour to the other man, that ought your money by the bill, as in the. 39 . parcell ${ }^{5}$.

En su segunda obra de 1568, mucho más extensa y detallada, el Maestro (Scholemaster), pronuncia las mismas palabras que más tarde repetiría Mellis en su edición de Oldcastle, aunque el discípulo (Scholler) dice que es capaz de responder de memoria, pero sin utilizar razonamiento alguno (I am alreadie able to aunswere (...) by rote, but the reason thereof I understande not $)^{6}$. La franqueza del discípulo está compensada con un número mayor de ejemplos, cada uno seguido de su cargo y abono. El número de ejemplos en esta ocasión asciende a 187.

Ya en el siglo XVII, la norma general permanecía y el número de ejemplos se acrecentaba. Richard Dafforne, en The Merchants Mirrour (1635) -el primer tratado en lengua inglesa que conoció numerosas ediciones-, presenta quince reglas de ayuda (Rules of aide) que nos ofrecen un retrato de la actitud y metodología de presentación del maestro. Las cuatro primeras son las siguientes:

Rules of aide, very requisite in Trades continuance, to be learned without booke.

1. Whatsoever commeth unto us (whether Mony, or

Wares) for Proper, Factorage, or Company account, the same is Debitor.

2. Whosoever Promiseth, the Promiser Debitor.
1. Whatsoever goeth from us (whether Mony, or Wares) for Proper, Factorage, or Company account, the same is Creditor.

2. Unto Whom wee Promise, the Promised man is

Creditor.

James Peele, The maner and fourme how to kepe a perfecte reconyng, after the order of the moste worthie and notable accompte of Debitour and Creditour..., Imprinted at London, by Richard Grafton, printer to the Kinges Maiestie, 1553, capítulo IV.

6 James Peele, The Pathe waye to perfectnes, in th'accomptes of Debitour, and Creditour: in manner of a Dialogue..., Imprinted at London, in Paules Churchyarde. By Thomas Purfoote, dwellinge at the signe of Lucrece, [1569]. 
3. Unto whom wee pay (whether with Money, Wares, Exchanges, Assignations) being for his owne account: that man is Debitor.

4. Unto whom we pay (as above) for another mans account:

The man for whose account we pay is Debitor.
3. Of whom wee receive (whether Mony, Wares, Exchanges, Assignations) being for his owne account: that man is Creditor.

4. Of whom wee receive (as above) for another mans account:

The man for whose account wee receive is Creditor. ${ }^{7}$

Las reglas pretendían cubrir todo tipo de operación que un tenedor de libros pudiera encontrarse. Con tal fin las normas se fueron ampliando hasta finales del siglo XVIII. En su The Apprentices TimeEntertainer... (1670), Richard Dafforne dobla el número de sus normas de ayuda (rules of aide), si bien parece valorar el papel que puede desempeñar la memoria. Así, como elemento nemotécnico, traduce las reglas que Johannes Buingha recoge en su tratado holandés de $1627^{8}$ :

Who the Debitor is, or oweth

1. What we have

2. Whoso receiveth

3. What we buy

4. Unto whom we sell

5. For whom we buy

6. Whoso must pay

7. For whom we pay

8. What we cause to be insured

9. For whom we insure

10. Whither-wards we send

11. That which is gained upon

12. Profit and Loss
Who the Creditor is, or must have

1. Whence it arriveth

2. Whoso giveth out

3. Of whom we buy

4. That which is sold

5. They of whom we buy

6. They that must have

7. Wherewith we pay

8. The Assuror

9. Insurance reckoning

10. What we send away

11. That which is lost

12. Profit and Loss

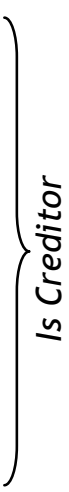

7 Richard Dafforne, The Merchants Mirrour: Or Directions for the Perfect Ordering and Keeping of His Accounts; Framed by way of Debitor and Creditor, after the (so termed) Italian-manner: containing 250 Rare Questions, with their Answers, in forme of a Dialogue, London: Printed by R. Young, for Nicolas Bourne, at the South-entrance of the Royall Exchange, 1635.

8 Johannes Buingha, Oprecht Fondament Ende principalen inhout van het Italiaens Boeck-houden. Om van alle Partyen den Rechten Debiteur, ende Crediteur te stellen, die selve int cort op t'groot Boeck, over te draghen: Mitsgaders een grontlijcke onderrichtinghe, om een y eghelijcx Reeckeninghe in Debito, ende Credito van t'groot Voeck wel te verstaen, zijride t'voornaemste des Boeck-houdens, t'Amstelredam: By Willem lansz, Stam Boeckvercooper, 1627. 
La costumbre de incorporar casos o ejemplos numerosos prosiguió en el siglo XVIII. Edward Hatton en su obra The Merchant's Magazine (1701) presenta veintinueve casos para "Proper [sole trader's] accounts in Domestick Trade"; dieciocho para "Accounts proper in Foreign Trade"; seis para "Factorage [agent's] Accompts in Domestick Trade"; cinco casos de "Factorage Accompts in Foreign Trade"; y dieciseis de "Company [partnership] Accompts"10.

Charles Snell, después de su tratado Rules for Book-keeping According to the Italian Manner... (1701), publicado el mismo año que el de Hatton, que consta de once páginas de normas, de un total de setenta ${ }^{11}$, escribió el volumen The Merchants Counting-House (1718), que se compone de sesenta y nueve reglas ${ }^{12}$. William Taylor en su libro A Complete System of Practical Arithmetic (1783) tan solo incorpora veintiuna normas, quizás porque se ocupa de la partida simple y doble en una breve extensión de veintitrés páginas ${ }^{13}$.

J.H. Lewis, por su parte, en el tratado The Quick and Easy Method of Teaching Book-keeping... (1860), señala en el Prefacio que los estudiantes

... have been discouraged in their first attempts to acquire a knowledge of the art, as they were confounded by the multiplicity of rules and examples; for, the various entries in the Waste-book, Journal, and Ledger, being both numerous and prolix, made it almost impossible they should have a just conception of their tendency. For the sake of such, the Author of this work has therefore made the examples few and the rules for posting and balancing plain and easy to be comprehended. In short, he has endeavoured to unite the elementary instructions

9 Richard Dafforne, The Apprentices Time-Entertainer Accomptantly: Or A Methodical means to obtain the Exquisite Art of Accomptantship: Digested in Three Parts..., London: Printed by W. Godbid, for Robert Horne and are to be sold at his shop at the South Entrance of the Royal Exchange in Corn-hill, 1670, [1640].

10 Edward Hatton, The Merchant's Magazine: or, Trade Man's Treasury..., London: Printed by E.M. for Chr. Coningsby at the Ink-Bottle near St Dunstan's Church in Fleestreet; and Dan. Midwinter at the Rose and Crown in St. Paul's Churchyard, 1707 [1701].

11 Charles Snell, Rules for Book-keeping, According to the Italian Manner: Now in General Use. Directing Young Accomptants to the Books and Accompts, Where the Usual Occurrences in Trade Are to Be Enter'd; and in the Stile proper for such Entrances, London: Printed for John Place, at Furnivals-Inn-Gate in Holborn, 1701.

12 Charles Snell, The Merchants Counting-House: Or Wast-Book Instances, with Directions for Their Stating and Entrance..., London: Printed for Jonas Brown, at the Black Swan without Temple-Bar, 1718.

13 William Taylor, Complete System of Practical Arithmetic: With Various Branches in the Mathematics, Birmigham: Printed and Sold by the Author, 1783. 
of the schoolmaster with the practical improvements of the merchant; and persons who understand this treatise will soon be able to comprehend the business of any counting house ${ }^{14}$.

Lewis nos presenta cuarenta y siete reglas.

A pesar de tantos y tantos ejemplos y normas, los autores eran conscientes de la dificultad de aprender la materia mediante reglas, lo que les llevó a intentar una mejora en la presentación de las mismas. Y así lo hicieron de tres maneras: primero procuraron explicarlas con mayor claridad; segundo, las pusieron en verso; y tercero, se realizó una clasificación de normas.

John Collins, por ejemplo, en su Introduction to Merchants Accounts (1653) se entregó a un análisis minucioso de las normas que rigen el registro de diversas secciones de la teneduría de libros, aunque por razones tipográficas, o de otra índole, nadie continuó con su labor pionera. Mucho más popular fue la utilización de ripios como ayuda nemotécnica ${ }^{15}$.

III

La versificación tiene una larga y acreditada historia en la teneduría de libros. Domenico Manzoni en su Qvaderno doppio col svo giornale (1540) ya expone sus normas en verso:

Nota che la Regola del Giornale \& Quaderno, in se contiene sei cose, cioe Dare, Hauere, Qualità, Quantità, Tempo \& Ordine.

Dare significa douer dar, cioe il debitore, o uno o piu che siano.

Hauere, uuol dir douer hauere, cioe il creditore, o uno o piu che siano.

Qualità, sono quelle cose che tu maneggi, \& siano di che sorte si uogliono.

Quantità, è il numero peso ouer misura, o piccioli, o grandi che si siano.

14 James Henry Lewis, The Quick and Easy Method of Teaching Book-keeping According to the English, Italian, and Scotch Systems of Single Entry and Double Entry Exemplified in Individual and Partnership Accounts, Both Domestic and Foreign. Forming a Branch of The Royal Lewisian System of Commercial Education, London: Printed for the Author and Sold at His Only Institution, 1869, p. xvi.

15 John Collins, An Introduction to Merchants Accounts Containing Five Distinct questions of Accounts..., London: Printed by James Flesher for Nicholas Bourn, at the South entrance of the Royal Exchange, 1653. 
Tempo, si è il giorno, il mese, \& l'anno, sotto ilquale tu fai la partida.

Ordine, quello, che nella presente opera con facilita insegnamo ${ }^{16}$.

Por lo que se refiere a Gran Bretaña, es indudable que el padre de la versificación en la partida doble fue James Peele, padre de George Peele, dramaturgo isabelino. Al comienzo del Diario que recoge en su primera obra, The maner and fourme, leemos:

\section{Rules to be ob-} serued

Yf that in this accompt, these preceptes ye obserue, than I you wel assure, no part therof shall swerne.

To make the thinges receiuyd, or the receiuer, Debter to the thinges deliuered, or to the deliuerer. And to reciue before you write, and write before you paye, So shall no parte of your accompt, in any wyse decaye.

Obserue wel these rules, your lournall boke throughout, So shall you make sure worke, of that you go about ${ }^{17}$.

Los versos de Dafforne, que encontramos al inicio de su Libro Mayor, recogido en The Merchants Mirrour, son más sencillos:

$$
\text { In Briefe, }
$$

The Ower, or the Owing Thing,

Or what-so-ever comes to thee:

Upon the Left-hand see thou bring;

For there the same must placed be.

$$
\text { But }
$$

they unto whom thou doest owe, Upon the Right let them bee set;

Or what-so-eve doth from thee goe,

To place them there doe not forget ${ }^{18}$.

Aunque los poemas se fueron haciendo más breves y el vocabulario se volvió más sencillo, la versificación se convirtió en algo habitual en el siglo XIX. P. Kelly, en The Elements of Bookkeeping; Comprising A System of Merchants Accounts (1801), una obra clásica de la época, podemos leer:

16 Domenico Manzoni, Qvaderno Doppio col svo giornale, novamente composto, \& diligentisimamente ordinato, secondo il costume di Venetia. Opera a ogni persona utilissima, \& molto necessaria. Cvm gratia et privilegio del Ilustrissimo Senato di Venetia, per Anni diece, 1540.

17 James Peele, The maner and fourme, ed. cit.

18 Richard Dafforne, The Merchants Mirrour, ed. cit. 
By Journal laws, what I receive

Is debtor made to what I give;

Stock for my Debts must debtor be,

And Creditor my Property.

Profit And Loss Accounts are plain

I debit Loss and credit gain ${ }^{19}$.

Geo H. Boulter en el Prefacio de su tratado A Course of Bookkeeping by Double and Single Entry... (1857), después de citar los versos de Kelly, refiriéndose al alumno, dice:

He then posts them into the Ledger, wondering all the time why the same transaction is entered on the Dr. side, and again on the Cr. side, (for we must remember that the principle of Double Entry has not been explained to him) and sorely puzzled to discover the meaning of those mysterious terms $\mathrm{Dr}$. and $\mathrm{Cr}$. when applied to any other than personal accounts ${ }^{20}$.

IV

La tercera y más importante mejora que los docentes procuraron en el uso de las normas, se refiere a la clasificación. Esta tendencia marca el comienzo de una búsqueda: hallar una regla general y sencilla que fuera aplicable a cualquier tipo de operación.

John Carpenter en su obra A Most Excellent Instruction for the Exact and Perfect Keeping Merchants Bookes of Accovnts... (1632) agrupa las normas en varias categorías. Veamos las tres primeras del apartado que se ocupa "Of receiving and buying money by bils of Exchange":

1 If any one deliver you a Bill of Exchange, which you send to another; you are to make him to whom you send it, Debtor to him that underwrit it.

2 Contrarily, if you deliver a Bill of Exchange to any one, which you have taken up upon another, you shall make

19 P. Kelly, The Elements of Bookkeeping; Comprising a System of Merchants Accounts, Founded on Real Business, and Adapted to Modern Practice: With An Appendix on Exchanges, Including the Recent Alterations, Edinburgh: 1801.

20 Geo H. Boutler, A Course of Bookkeeping by Double and Single Entry, As Applied to Inland and Foreign Trade, Containing the Most Recent Improvements Both in the Method of Teaching, and in the Practice of the Art. Adapted to the Use of Schools or Self-Instruction, London: Printed and Published by John Mabley, 143, Strand, 1847, p. ii. 


\begin{abstract}
him to whom you deliver it, Debtor to him upon whom you have charged it.

3 When one accepteth a Bill of Exchange which is sent to you, you are to make him who accepted the same, debtor to him who sent it you ${ }^{21}$.
\end{abstract}

Otro pionero en el campo de la clasificación fue Thomas Browne. En su libro The Accurate Accomptant (1670) realiza un "Analysis", que ocupa una página doble, del tamaño de un pliego, en la que intenta reducir una multitud de normas en una clasificación coherente. Así agrupa todas las normas referentes a mercaderías (wares or goods) y pasa a analizar las que se refieren a compras de la siguiente manera:

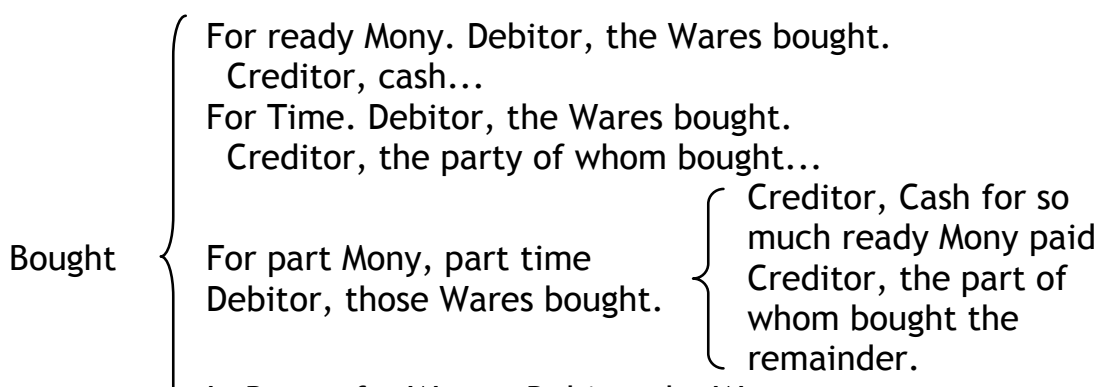

In Barter for Wares. Debitor the Wares received. Creditor, the Wares delivered. If both of equal value ${ }^{22}$.

Mathew Quin, a su vez, hizo un recorrido similar en sus Quin's Rudiments of Bookkeeping (1776). Simplificó la clasificación en seis casos. Cada uno de ellos es un ejemplo de un apartado de la teoría de teneduría de libros:

THE SIX PLAIN CASES proposed in the title of my present plan are these

1st. To form a List or Inventory of my whole stock to begin trade with; and another, of what Debts I owe.

2d, is Buying;

21 I. Carpenter, A Most Excellent Instruction for the Exact and Perfect Keeping Merchants Bookes of Accovnts, By Way of Debitor and Creditor, after the Italian Manner: Most Vsefvll for all Merchants, Factors, And Tradesmen..., London: Printed by I.B. for lames Boler, and are to be sold at the signe of the Marigold in Pauls Churchyard, 1632, p. 57.

22 Thomas Browne, The Accurate Accomptant or London-Merchant.... Also a Journal and Leager.... With An Addition of An Accompt Partable, Wherein Four Persons Are Mentioned to Joyn in Partnership Upon Two Several Designs: in Both Which, They All Have Different and Unequal Parts. With A Question Concisely Stated And Resolved..., London: William Godbid for John Hancock, 1670. 


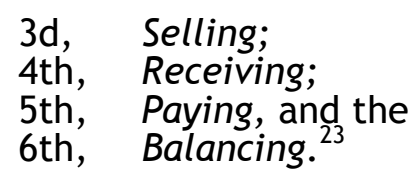

Con todo, no sería hasta bien entrado el siglo XIX, cuando las tres reglas de oro -una por cada una de las tres cuentas más importantes-, fueron generalmente aceptadas como método habitual de exposición.

La metodología didáctica del enfoque del Libro Diario a la teneduría de libros y la aplicación de normas se produjo como vamos a ver a continuación. En primer lugar, hay que encontrar la norma en el libro de texto que mejor se ajuste a la operación que hay que anotar; hay que cotejar el folio del Borrador y localizar la mencionada operación en el Diario y en el Mayor. Esto es, en esencia, lo que Thomas King nos dice en las instrucciones de su manual An Exact Guide to Book-keeping (1717) ${ }^{24}$.

Las instrucciones para profesores (Directions to Teachers) que Robert Hamilton recoge en $A$ Short System of Arithmetic and Bookkeeping (1788) son típicas:

In teaching book-keeping by double-entry, the chief point is to convey to the learner a distinct notion of the nature of $\mathrm{Dr}$. and $\mathrm{Cr}$. and the contents of the accompts in the ledger. After he has been thoroughly instructed in the eight principal rules for journalizing (...) and has carefully perused the detail of the ledger accompts (...) he is to proceed to transcribe a portion of the wastebook, and try the computations; then he is to write in a scroll-book that part of the journal which is printed in italics, which expresses the Drs. and Crs. of the several articles. When this is done, it is to be compared with the printed journal, or examined by the teacher; then the narrations are to be filled up, and a fair copy of the whole transcribed into the journal ${ }^{25}$.

23 M. Quin, Quin's Rudiments of Bookkeeping; Comprised in Six Plain Cases, and Attainable in as Many Days, Without the Help of a Teacher. Calculated for Persons of Either Sex, Grown to Maturity. With An Essay on the Fit Manner of Initiating Youth to Temperance and Moral Rectitude; By An Easy Arithmetical Scale, London: Printed and Sold by J. Bew, Pater-noster Row; also by W. Davenhill, Cornhill, and J. Walter, Charing Cross, 1776, pp. 10-11.

24 Thomas King, An Exact Guide to Book-keeping by Way of Debtor and Creditor: Done After the Italian Method..., London: S. Cruttenden, 1717.

25 R. Hamilton, A Short System of Arithmetic and Bookkeeping. With $A$ Supplement; Containing Answers to the Arithmetical Questions, London: Printed for C. Elliot \& T. Kay, №332, Strand; and Edinburgh: C. Elliot, 1788; "Directions to Teachers", p. vi. 
La enseñanza, a base de repetición de memoria, parece que fue uno de los pilares más fuertes de instrucción. John Matheson, en The Theory and Practice of Book-keeping (1818) propone un modelo de ejercicio para el alumno, que después revisará su profesor:

Q. Sold A. B. ten puncheons of rum, per bill at six months, required the Journal Entry?

A. Bills receivable Dr. to Rum, because a bill is received in payment of goods delivered, per rule $4 \mathrm{th}^{26}$.

Los rasgos pedagógicos más significativos de los primeros 250 años de docencia en teneduría de libros quedan aquí expuestos de forma admirable. En primer lugar, se destaca el Diario como libro importante de registro $y$, en segundo lugar, el uso de reglas para determinar la anotación que sea menester.

Y, al mismo tiempo, autores y docentes se empeñaban en una mejora de los métodos de enseñanza que redujeran las grandes limitaciones que aquellos métodos podían tener. En concreto, es de destacar el desarrollo de los ejercicios para los alumnos. En los textos más tempranos, la teoría de la materia, por lo general, estaba ilustrada con un juego de libros (Borrador, Diario y Mayor), si bien, habrían de pasar más de 150 años para que se reconociera el valor del Borrador como ejercicio para el alumno.

Al comienzo de The Merchants Mirrour (1636), Dafforne escribe una epístola "To the Book-keeping Teachers" en la que, entre otras cosas, dice:

Daily experience approveth, that we which submit our selves to teach several Mothers children, are subject to the censure of many. Neverthelesse, I have imboldened my selfe to divulge this part of my labour, it being the first since I pitched my abode in London; but particularly (as very requisite) I dedicate the First and Second Waste-bookes unto you, not as teaching, but necessary assisting bookes: especially for such as have no opportunity to compile a Waste-booke for their Schooles proper use.

Here you have matter to exercice your Scholars in diversities of accompts, and after severall manners of entrances, for the effecting of the same: the like (though

26 John Matheson, The Theory and Practice of Book-keeping.... Remarks on Bills and Promissory Bills; The Nature of Trade..., London: 1818, p. 73. 
spoken $_{27}$ by mee) I have not seened presented to my nation $^{27}$.

Con estas palabras nacía el primer libro de ejercicios de teneduría de libros. Años más tarde, Dafforne, en The Apprentices TimeEntertainer (1640) alude a dos Borradores para ejercicios y añade:

Here in these two Waste-books (which, by the scarcity of them in General, seem to be very difficult in their Composition; else they would be more common in our Schools.... $)^{28}$.

Ya en el siglo XVIII, Alexander Malcolm, en A Treatise of Bookkeeping, or, Merchants Accounts (1731) señala que los estudiantes deberían utilizar los ejemplos del Borrador:

... as there is a great Variety of Examples of Business in the two Waste-Books, they may considerer those as so many Questions proposed, in order to find the Debtors and Creditors; (which is the Purpose of all the tedious Instructions given in the Way of Question and Answer) and in the Journal they have the solutions ${ }^{29}$.

Medio siglo después Robert Hamilton continuó con esta línea en los "Sets for Practice" de su tratado An Introduction to Merchandize (1777). Y como prueba de perfeccionamiento en la presentación, dispuso dos ejemplos de Borrador y Diario en páginas opuestas para que el lector los pudiera comparar ${ }^{30}$.

A finales del siglo XVIII el Borrador se había convertido en un buen utensilio para la práctica. J.H. Wicks, "Master of the Boarding School, Englefield-House, Egham, Surry", incorporó como materia de curso de su texto Book-keeping Reformed... (1797) un segundo Borrador para

27 Richard Dafforne, The Merchants Mirrour, ed. cit.

28 Richard Dafforne, The Apprentices Time-Entertainer, ed. cit.

29 Alexander Malcolm, A treatise of Bookkeeping, or, Merchants Accounts; in the Italian Method of Debtor and Creditor.... The Whole Illustrated and Exemplified with Two Sets of Books, Containing Great Variety of Practice in All those Branches of Business, London: Printed for J. Osborn and T. Longman, in Pater-noster-Row; F. Fayram and E. Symon, at the Royal Exchange, 1731, p. 35.

30 Robert Hamilton, An Introduction to Merchandize. Containing A Compleat System of Arithmetic. A system of Algebra. Book-keeping in various forms. An Account of the Trade of Great Britain, and the Laws and Practices which Merchants are Chiefly Interested In, 2 vols., Edinburgh: Printed for the Author; Sold by T. Cadell, London, and John Balfour, Edinburgh, 1777, vol. I, p. 29. 
aquellos que deseasen realizar más práctica ${ }^{31}$. Prometió publicar un Libro Diario y un Mayor para uso de los docentes, aunque si lo hizo, nosotros no hemos dado con su rastro.

No obstante, los ejercicios del Borrador eran extraordinariamente largos. La práctica de acompañar la teoría de la materia con un juego completo de libros y uno o más Borradores fue habitual hasta bien avanzado el siglo XIX. Así, el libro de Hamilton y Ball, Book-Keeping (1869), texto que fue muy popular entre 1870 y 1890 , recoge que ambos fueran examinadores de la Society of Arts. Dispone de un único y extenso ejercicio, que contiene gran variedad de operaciones, todas ellas desarrolladas en su totalidad ${ }^{32}$. J. Thornton en su texto First Lessons in Book-keeping (1879) considera digno de destacar que, en lugar de una serie de ochenta o cien transacciones, lo que significaría un trabajo de seis meses, él tan sólo ofrezca una serie breve de tres con la que comenzar ${ }^{33}$. G. F. C. Vernon publicó, en 1893, Sets for Practice in Book-keeping. Se trata de un libro de ejercicios. El autor señala en el Prefacio:

Long experience has taught the Author the necessity of providing his Pupils with such sets for practice as may be properly worked within the limits of one or two lessons. The sets in the present collection have actually been worked out with classes, under these conditions ${ }^{34}$.

A comienzos del siglo XX, el Borrador, primer libro del sistema italiano, se había transformado. Había pasado de un registro de innumerables y misceláneas operaciones a una serie de ejercicios breves directamente relacionados con el capítulo correspondiente del libro de texto. Es interesante especular hasta qué punto la evolución del Borrador en un libro de ejercicios ha fraguado en la práctica de enseñar teneduría de libros con operaciones recogidas en un manual en lugar de hacerlo con documentos reales. Esta técnica, sin duda, separó todavía más el aula de los negocios.

31 J.H. Wicks, Book-keeping Reformed..., Egham: 1797. "Dedication".

32 R.G.C. Hamilton and John Ball, Book-Keeping, Oxford: At the Clarendon Press,

1869.

33 J. Thornton, First Lessons in Book-keeping, London: 1879.

34 G.F. Carr Vernon, Sets for Practice in Book-keeping, London: Sold by Charles Chappell, 3 Brecknock Road, N.W., 1893; "Preface". 
V

La exposición mediante la repetición de un conjunto de normas ocultó el hecho de que los autores de libros de texto sostenían, de forma consciente o inconsciente, una de las dos teorías de cuentas existentes. Esto es palmario por las contadas ocasiones en las que los autores intentan explicar o razonar sus normas. Por una parte existía un grupo que pretendía personificar las cuentas, mientras que, por otra, nos encontramos con un grupo reducido, con cierto peso en Estados Unidos, que sostenía lo que podemos denominar como teoría de cuentas de propiedad (ownership).

La atribución de una personalidad viva e independiente tiene sus raíces en las primeras formas de la teneduría de libros. Cuando menos tuvo dos fuentes. En primer lugar, no cabe duda de que los primeros Libros Mayores mostraban las relaciones de deuda entre comerciantes ${ }^{35}$. Con el desarrollo del sistema de la partida doble, los términos deudor y acreedor se hicieron extensivos, en primer lugar a cuentas de objetos (cuentas de existencias) y, posteriormente a clasificaciones abstractas (cuentas nominales). Por consiguiente, se hizo habitual ampliar el significado de los términos débito y crédito más allá de la connotación personal original y aplicarlos a objetos inanimados y conceptos abstractos. El proceso en sí mismo forjó un instrumento pedagógico.

Otra fuente que impulsó el concepto de la personificación es la práctica de registrar las relaciones financieras entre el propietario de una hacienda y su administrador o contable en la forma de una cuenta de cargo y abono. El administrador se cargaba con la parte de la propiedad que se le había confiado, incluídos todos los recibos aceptados en representación del señor y se abonaba con los gastos realizados en nombre de su patrón y el dinero pagado al propietario de la hacienda. El uso del término cargo se amplió desde su aplicación personal a la de cuentas de cargo. Cualquiera que fuera su origen, la práctica de explicar cómo deben anotarse las partidas en el Libro Mayor, mediante la personificación de cuentas, la encontramos en los primeros tratados británicos y guarda una estrecha relación con el origen del sistema de teneduría de libros.

35 Edward Peragallo, Origin and Evolution of Double Entry Bookkeeping. A Study of Italian Practice from the Fourteenth Century.... New York: American Institute Co., 1938, p. 1. 
Podemos identificar tres formas principales de personificación. En la primera se considera a la cuenta como una entidad independiente y viva. En la segunda, la cuenta representa al propietario del negocio. Finalmente, existe una combinación de estas dos formas en la que imaginamos que la cuenta es un individuo distinto del propietario, aunque él sea el último responsable. Estas tres formas, con frecuencia, están entrelazadas de modo inextricable en cualquier texto $\mathrm{y}$, desde el punto de vista histórico, se fueron desarrollando al unísono.

La forma original veneciana de una partida del Diario era prologar la cuenta en la que se cargaba con un PER y la cuenta de abono con una A. Estas palabras eran meros términos técnicos que habían perdido su significado gramatical. A la hora de traducir, los autores no encontraron términos ingleses que correspondieran directamente y se manifestaron reacios a acuñar unos nuevos. Así, para los términos italianos debito y credito, entendieron que correspondían a oweth y trusts, términos de relación que sólo son aplicables a personas. Partidas que en el tratado de Pacioli tenían la forma "PER caja, A capital", después de la traducción de Oldcastle adoptaron la forma "Money oweth to Thomas Lee". El dinero (money) adquiría una existencia personal independiente. James Peele utilizó una secuencia de palabras similar. A su vez, el enigmático W. P., en su tratado The Pathway to Knowledge (1596), anota las partidas del Mayor con la frase Peter Garetson ought to give to money..., cuando se trata de cargar en la cuenta personal. Y utiliza las palabras ought to have of cuando son cuentas acreedoras. Estas frases indican la imagen mental que los autores tenían del dinero y de otras cuentas de existencias: les atribuían cualidades humanas ${ }^{36}$.

A comienzos del siglo XVII las partidas del Diario ya eran muy similares a las modernas en su forma: $X$ Debtor to $Y$. De esta expresión de la partida es de donde se deriva la explicación. En la obra de Richard Dafforne, The Merchants Mirrour, se produce un diálogo entre el maestro "Philo-Mathy" y el discípulo "School-Partner" en los siguientes términos:

Phil. How booke you the Ready mony after the way of Debitor and Creditor?

Sch. Cash Debitor to Stocke.

36 W.P., The Pathway to Knowledge. Conteyning Certaine Briefe Tables of English Waights and Measures..., Written in Dutch and Translated into English by W.P., London: William Barley, 1596. 
Phil. Why make you Cash Debitor?

Sch. Because Cash (having received my mony into it) is obliged to store it againe at my pleasure: for Cash representeth (to mee) a man, to whom I (only upon confidence) have put my mony into his keeping; the which by reason is obliged to render it backe, or, to give mee an account what is become of it: even so, if cash be broken open, it giveth mee notice what's become of my mony, else it would redound it wholly backe to mee ${ }^{37}$.

La cuenta de caja, que Pacioli denomina "cassa", y que Oldcastle traduce de forma errónea por chest, es la cuenta más fácil de personificar, pues el receptáculo para el almacenamiento de monedas lo podemos imaginar y verlo como receptor (receiving) y pagador (paying).

El concepto de personificación, por extensión, se aplicó a objetos inanimados (cuentas de existencias), en lo que Alexander Malcolm denomina "... artificial and improper Sense, which is borrowed from Persons". Así lo afirma en 1731 en el tratado que ya hemos considerado, $A$ Treatise of Book-keeping. Y añade:

... when any Thing becomes mine, I consider it as a Subject which owes, or is accountable to me for such a Sum of Money as it has cost me, either in Specie, or other Effects, or I owe for it ${ }_{38}$ or which I expect to make out of it (cost what it will)... ${ }^{38}$.

En The Pathe waye to perfectness (1569), James Peele, por boca del maestro, es más explícito y advierte al discípulo:

Then marke me well, and I declare the same to you in few wordes. where as I saide before, that the thinges receaued must owe, I meane therby that the goodes bought, or monie receaued of anye man, must in all percelles be made debetour, (that is to saye) to owe unto the parties of whom it is receaued or bought. As for example, Imagine that you haue bought clothes of William Jones, then obserue the rule you must enter the percell in your Journall sayinge, Clothes oweth to William Jones. \& c. Yf you receaue monie of anye man, accordinge to the same rule you must saye, Monie oweth to Frauncis Taillor. \& c. and hereby it apperes in that parte, howe

37 Richard Dafforne, The Merchants Mirrour, ed. cit., p. 9.

38 Alexander Malcolm, A Treatise of Book-keeping, ed. cit., p. 13. 
the same rule is obserued, contrarie wise if you sell goodes, or paye monie to anye, then to the obseruinge of the same rule, you shall saye, William Thomsome \& c. oweth to clothes, or Jhon Ball \& c oweth to money ${ }^{39}$.

Una explicación, o razonamiento, de este método de exposición lo encontramos en The Accountant and Geometrician de Benjamin Donn (1765):

As I may expect to make of [sell] my Goods as much as they cost me, they are in Effect the same to me as if their Value was due to me from some person: and as, in such Case, that Person would be Debtor, so I may make the Goods in my Possession Debtor for their first Cost ${ }^{40}$.

Otro desarrollo del principio de la personificación fue la evolución de la idea de que las cuentas que no sean personales también representan al propietario. Edmond Dégrange, en su tratado La Tenue des livres rendue facile (1795), es uno de los pioneros en señalarlo:

... pour se faire une idée exacte de ces comptes, il ne faut voir en eux que ceux du négociant dont on tient les livres, et il faut concevoir que débiter l'un de ces comptes, c'est débiter le négociant lui-même, sou le nom de ce compte en particulier.

C'est sur cette invention qu'est fondé l'art de tenir livres en partite double ${ }^{41}$.

No obstante, la idea básica puede derivar de los primeros ejemplos de teneduría de libros por partida doble ${ }^{42}$.Se entendía que el propietario debía registrarse dos veces para cada una de las transacciones.

\footnotetext{
and the Scholler...".

40 Benjamin Donn, The Accountant and Geometrician: Containing the Doctrine of Circulating Decimals, Loga rithms, Book-keeping and Plain Geometry..., London: 1765.

41 Edmond Dégrange, La tenue des livres rendue facile, ou nouvelle méthode d'enseignement à l'usage des personnes destinées au commerce, avec une nouvelle méthode pour tenir des livres en double partie, par le moyen d'un seul registre dont tous les comptes balancent journellement. Sixtième édition, revue, cossignée et augmentée, Paris: Hocquart \& Bordeaux, chez l'auteur et chez Filiatre [\&] de l'imprimerie de J. Foulquier, 1806, p. 9. Sobre la importancia y repercusión de la aportación de Dégrange, véase J. Lanero Fernández y E. Ortega Montes, "Algunas consideraciones historiográficas sobre la lógica de la Partida Doble y la clasificación de Cuentas", Pecvnia, 2 (2006), pp. 65-78; pp. 74-75. 1966 [1933], pp. 46-47.

${ }^{42}$ Cfr. A.C. Littleton, Accounting Evolution to 1900, New York: Russell \& Russell,
}

39 James Peele, The Pathe waye, ed. cit., "A dialogue betwene the Scholemaster 
Por ejemplo: si se compraban mercaderías a crédito a Z, el análisis que se derivaría es, siguiendo al Profesor Littleton: "Goods shall give to propietor (who now places the responsibility upon that account), $Z$ shall have or receive from propietor (what $Z$ now places in his hands) ${ }^{\prime \prime 3}$. Una ampliación de este concepto la encontramos en Dégrange: el propietario queda registrado en todas y cada una de las operaciones y con el fin de no entorpecer su cuenta personal con una partida por transacción, propone sus comptes généraux, representando todas ellas al comerciante ${ }^{44}$.

El concepto de que las cuentas representan al propietario pronto ganó terreno en Gran Bretaña. Así, a mediados del siglo XIX James Henry Lewis, en su ya mencionado tratado The Quick and Easy Method of Teaching Book-keeping... (1860), explica:

...by an ingenious and useful fiction, which has long been employed in book-keeping, the article received is always made Dr. to the person from whom it was received; and the person who receives an article is always made Dr. to the article which he has received. So that, instead of the merchant's name standing as Debtor or Creditor in his own books, he is personated by the goods: this is uniformly the practice in keeping books, whether the article received be goods, cash, or bills ${ }^{45}$.

La dirección que tomó el desarrollo de esta idea la podemos observar en un extracto de la obra de Philip Crellin, Bookkeeping for Teachers and Pupils (1892):

It is, indeed, the trader himself who is the owner of this property, it is he who receives and parts with it, and it is he who, it may be thought, should be debited and credited rather than "Goods". But the trader, it must be remembered, has several kinds of goods, has cash, and bills, and fixtures, and leases, \& c. and if all transactions occurring in these various forms of property were brought together into one account and entered under his name, it is evident that it would be very voluminous, and that it would be impossible without great waste of time to ascertain particulars regarding any one of them. Hence the advantage of sorting these several items,

\footnotetext{
43 Ibid.

44 Edmond Dégrange, La tenue des livres rendue facile, ed. cit., pp. 6-9.

45 James Henry Lewis, The Quick and Easy Method of Teaching Book-keeping, ed. cit., p. 41. La itálica es del autor.
} 
bringing together all that relate to the same thing, naming the accounts correspondingly, and treating them in the way of debiting and crediting as if they were living persons having charge of, and responsible for, the property to which they refer ${ }^{46}$.

No obstante, con el fin de indagar más en esta forma de personificación debemos volver sobre nuestros pasos.

VI

La teoría de la personificación más completa surge cuando se otorga una identidad personal a las cuentas de las que es responsable el propietario, aunque desde una perspectiva material sean completamente independientes.

A la quinta edición del tratado Elements of Arithmetic (1846), de Augustus de Morgan, se incorporó un anejo titulado "On the main principle of Book-keeping". Es, con toda probabilidad, la pieza más influyente en la docencia de la teneduría de libros que se publicó en el siglo XIX. Por lo que a la personificación respecta, hizo explícito y amplió, hasta su conclusión lógica, lo que con anterioridad estaba implícito en los métodos de enseñanza. Con este texto se inicia el movimiento que finalmente desembocó en el rechazo del Diario, principal escollo en el aprendizaje de la materia.

Indicios de la idea de de Morgan sobre la responsabilidad que los escribanos adquieren al asentar partidas en los libros de cuentas ya se aprecian en la obra de Richard Hayes, Modern Book-keeping (1731):

Now observe that each of those Particulars your Inventory does consist of, are therefore made Debtor to Stock [Capital] in your Leger, because they are in Effect so many Stewards to whom you intrust your Estate, and each of them are accountable to you for their several Parts of $i t^{47}$.

46 Philip Crellin, Bookkeeping for Teachers and Pupils With Accounts in Illustration, Exercices for Practice and A Glossary of Commercial Terms, London: Whittaker \& Co., White Hart Street, E.C., 1892, p. 26.

47 Richard Hayes, Modern Book-keeping, or, the Italian Method Improved; Containing Rules and Directions for Keeping ... Accompts by Double Entry, London: 1731, p. 4. 
Al año siguiente, en un libro del que no se conservan ejemplares, Lectures on Accompts (1732), de J. Clark, la teoría de la personificación se expresa en unas palabras que años más tarde, B.F. Foster recogió en su obra The Origin and Progress of Book-keeping (1852):

Lectures on Accompts; or Book-keeping after the Italian manner, in which the fundamental principles of the art are laid down, and some of the most material accompts exemplified and explained. By JOHN CLARK, Writing Master, \& c. London, 1732.

"Let it be supposed," says Clark, " that the account of Stock is a real person employed to take care of my state and to render an account of the improvement he has made of it. In a like manner, Cash, and all other accounts which I may have occasion to keep, may be considered as persons employed by Stock to take care of that part of my state with which they are entrusted, and to render an account thereof to Stock. Then Cash, or the person entrusted with the care of my money, owes to Stock so much as he is entrusted with. Upon this hypothesis every transaction must be considered as though it had been transacted between persons who managed affairs for me. For there can be no business transacted but between two or more persons; and as there is no such thing as a person being debtor, but that he must owe some other person, and for that reason whom he oweth is called creditor. Hence, if the ledger is to contain an exact register of all my transactions, they must be doubly or twice entered; that is, the sum that any person oweth must be entered in his account that oweth, and also in the person's account he oweth it to..."

El breve apéndice de de Morgan sobre teneduría de libros, que propone la personificación absoluta de todas las cuentas en la persona de un escribano u oficial no fue, según acabamos de ver, una propuesta novedosa por completo. Lo que sí hizo fue aparecer en un momento oportuno para adoptar una nueva metodología docente. La relevancia de de Morgan contribuyó a la aceptación y desarrollo de la nueva idea ${ }^{49}$ :

48 Citado en B.F. Foster, The Origin and Progress of Book-keeping: Comprising an Account of All the Works on This Subject, Published in the English Language, from 1543 to 1852, with Remarks, Critical and Historical, London: Printed for John Souter: Published by C.H. Law, 131, Fleet Street; Aylott and Jones 8, Paternoster Row; John Vandenbergh, 161A, Strand, 1852, pp. 13-14.

49 En la actualidad se reconoce que el Profesor de Morgan fue quien dio los primeros pasos en contabilidad matricial. 
The accounts are kept as if every different sort of account belonged to a separate person, and had an interest of its own, which every transaction either promotes or injures. If the student find that it helps him, he may imagine a clerk to every account: one to take charge of, and regulate, the actual cash; another for the bills which the house is to receive when due; another for those which it is to pay when due; another for the cloth (if the concern deal in cloth); another for the sugar (if it deal in sugar); one for every person who has an account with the house; one for the profits and losses; and so on.

All these clerks (or accounts) belonging to one merchant, must account to him in the end -must either produce all they have taken in charge, or relieve themselves by shewing to whom it went. For all that they have received, for every responsibility they have undertaken to the concern itself, they are bound, or are debtors; for everything which has passed out of charge or about which they are relieved from answering to the concern, they are unbound, or are creditors. These words must be taken in a very wide sense by any one to whom book-keeping is not a mystery. Thus, whenever any account assumes responsibility to any parties out of the concern it must be creditor in the books, and debtor whenever it discharges any other parties of their responsibility. But whenever an account removes responsibility from any other account in the same books it is debtor, and creditor whenever it imposes the same.

To whom are all these parties, or accounts, bound, and from whom are they released? Undoubtedly the merchant himself, or, more properly, the balance clerk, presently mentioned $^{50}$.

James Collier en Bookkeeping by Double Entry (1884) y S. Dyer en A Common-Sense Method of Double-Entry Bookkeeping (1897) adoptaron por completo las ideas expuestas por de Morgan. Dice James Collier en su Prefacio:

It is becoming an axiom in education that every subject taken up by the pupil should be made the means of exercising as many powers of the mind as possible, and not be merely an exercise of the memory. Hence we have appealed strongly to the imagination to create an array

50 Augustus de Morgan, Elements of Arithmetic, Sixth Edition, London: Edward Stanford, 55, Charing Cross, S.W., 1876, pp.181-2. 
of clerks who must be anything but dummies, and we have reasoned out everything from the principles enounced.

Some critics may object to the idea of clerks especially to Profit and Loss. We have, however, the authority of the late Professor A. de Morgan for this view. Will anyone assert it was not in the minds of the inventors of the art? Certainly in the course of some twenty five years' experience in teaching, we have constantly found it to be the "enlightening fact" to the learner, and the progress has commonly been in proportion to the learner's grasp of this notion ${ }^{51}$.

Collier explica las nociones fundamentals de la teneduría de libros de la siguiente manera:

In Bookkeeping the whole business is supposed to be carried on by clerks. There is supposed to be a clerk called Capital or Stock who represents the owner of the business (or the Firm). There is supposed to be a clerk called Goods who takes charge of the merchandise. There is supposed to be a clerk called Bills Receivable who takes charge of all "Bills" payable by the Firm. There is supposed to be a clerk called Bills Payable who takes charge of all "Bills" payable by the Firm. There is supposed to be a separate clerk for each and every person or firm with whom the Firm has credit transactions, i.e. transactions in which a debt is incurred. There is supposed to be a clerk called Profit and Loss who-

\section{RECEIVES:-}

All sums lost by the Firm, All money expended in Trade expenses, All discounts allowed by the Firm, All money withdrawn by members of the Firm.

These are all of the nature of Losses.
GIVES:-

All sums gained by the Firm All discounts allowed to the Firm.

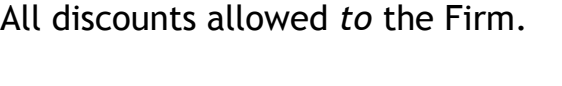

These are all of the nature of Gains.

There is supposed to be a clerk called Balance of whom we shall speak hereafter. We shall often use the word Sundries, but Sundries is not a clerk. The word means "two or more clerks named below."

N.B.- These clerks mind their own business and do not interfere in another's department. Thus, if perchance "Goods" receives some money he instantly hands it over to "Cash" because he himself has no business with money ${ }^{52}$.

51 James Collier, Bookkeeping by Double Entry: Familiarly Explained Together with Copious and Graduated Exercises, and a New Method for Dealing with Small Debts, London: Relfe Brothers, 6 Charterhouse Buildings, Aldersgate, E.C., 1884, pp. 5-6.

52 Ibid., pp. 10-11. 
Todas las operaciones se analizan en términos de movimientos de valor entre los escribanos u oficiales (clerks). Por ejemplo, la primera regla es:

RULE I.- In every transaction there is a clerk $(A)$ who gets something of a certain value from another clerk (B). Then $A$ is Debtor to $B$ and $B$ is Creditor by $A$ for that amount $^{53}$.

S. Dyer utiliza exactamente el mismo método, que denomina e incorpora al título de su obra como A Common Sense Method of DoubleEntry Bookkeeping (1897). La aceptación de una personificación absoluta estaba en consonancia con la oposición al prendizaje de memoria, que se produjo en Gran Bretaña en la segunda mitad del siglo XIX ${ }^{54}$.

Al explicar la estructura de las cuentas mediante la forma de una relación de deuda, los docentes reconocían, de modo explícito, la dificultad de presentar la teneduría de libros en términos personales. $\mathrm{Y}$, aunque un tanto inadecuados para explicar las partidas que se deben anotar en las cuentas personales, el significado de los términos deudor y acreedor tuvo que llevarse hasta el absurdo a la hora de abordar las cuentas nominales y de existencias.

Edward Thomas Jones fue el primer contable que formuló un ataque frontal contra el sistema establecido de teneduría de libros por partida doble y, consecuentemente se burla de sus métodos de exposición en Jone's English System of Book-keeping by Single or Double Entry (1796):

... Why should a Merchant's, or tradesman's Book be stuffed with such ridiculous and mysterious nonsense, as appears on every leaf of those kept by Double Entry. Such as "Sundry Accounts debtor to Sundry Accounts; - $A$. $B$. Dr to Wine; - Wine Dr to Profit and Loss: C.D. Dr to Deals, \& c. \& c. Now if A. B. owes Wine money, why not let Wine call for payment? But if A. B. do not owe Wine money, why make the entry in such way as only tends to confuse the mind of a person who is not a good accomptant? It will be replied, that this is necessary to form the plan of Double Entry. But as I am confident that no Man in WHOLE COMMERCIAL WORLD can take a set of Books, kept after the Italian Method, and prove in those

53 Ibid., p. 11.

54 S. Dyer, A Common Sense Method of Double-Entry Bookkeeping on First Principles. As Suggested by De Morgan, 2 vols., London: George Philip \& Son, 32 Fleet Street, E.C., 1897. 
Books that they are right, I shall insist upon it, that no persons in trade ought to keep their Books by that method, as they are continually liable to be injured by fraud or mistakes, and that therefore the Italian method of Book-keeping ought to be totally ABOLISHED ${ }^{55}$.

B.F. Foster, siempre dispuesto a anunciar las ventajas de sus libros de texto y de su método, enseñó, en exclusiva, en su "establecimiento" de Londres, situado en 161a Strand, no tuvo inconveniente en reproducir algunos ejemplos confusos como uno, que vemos a continuación, tomado de The Whole Science of Double-Entry Book-keeping (1850) de Daniel Sheriff ${ }^{56}$ :

"Robert Henderson Dr. to Bills Payable.........£337.10s."

"Elucidation.- Henderson is debtor because he owes us, we having paid him the amount that we owed him. Bills payable are creditor, because the note to which that title is given has paid Henderson for us; therefore we owe it" ${ }^{\mathrm{nt}}$.

Podría ser interminable citar ejemplos similares de los textos contemporáneos. Collier, utilizando la personificación completa de de Morgan, se ve obligado a explicar:

When we write "Cash debtor to Goods $€ 50$," it does not necessarily mean that the cash-clerk owes the goodsclerk (the creditor) has discharged a debt of $£ 50$ owing by him to the cash-clerk. It means that the cash-clerk has got (or received) $€ 50$ from the goods-clerk and of course that the latter has parted with £50 (or its value) to the former ${ }^{58}$.

En pocas palabras: el significado aceptado de deudor y acreedor ni siquiera es satisfactorio en este contexto. Ridiculizar la

55 [Edward Thomas Jones], Jone's English System of Book-keeping by Single or Double Entry, in Which It Is Impossible for an Error of the Most Trifling Amount to Be Passed Unnoticed; Calculated Effectually to Prevent the Evils Attendant on the Methods so Long Established; And Adapted to Every Species of Trade..., Bristol: Printed by R. Edwards and sold by the author: by Grosvenor and Chater, Stationers, 1796, p. 26.

56 Daniel Sheriff, The Whole Science of Double-Entry Book-keeping, Simplified by the Introduction of an Unerring Rule for Debtor and Creditor, Calculated to Insure a Complete Knowledge of the Theory and Practice of Accounts. Designed for the Use of Merchants, Clerks, and Schools, London: Printed by J. Brown \& Co., Paternoster-Row, 1850.

57 B.F. Foster, The Origin and Progress of Book-keeping, ed. cit., p. 31.

58 James Collier, Bookkeeping by Double Entry, ed. cit., pp. 10-11. 
exposición del método de personificación es muy sencillo. Así, Charles Sprague, en Estados Unidos, llegó a escribir una sátira referente a cómo saldar el Libro Mayor, incluyendo el reparto. Se trata de The Bookkeeper (1882):

Stock, a merchant

Balance, his accountant

Cash, keeper of the money chest

Merchandise, a salesman

Wm. Receivable, protector of the portfolio

\author{
Profit-and-Loss, the economical \\ business-manager. \\ Expense, his subordinate, \\ a spend-thrift, but good- \\ hearted \\ Smith, Jones, Brown, \\ Sundries, Wm. Payable, and \\ others, friends and \\ customers $^{59}$
}

Esta obra literaria no estaba más lejos de la realidad que algunos libros de texto.

La explicación de las cuentas nominales es la bestia negra del enfoque de personificación, pues estas cuentas son meras abstracciones. El problema de su explicación no se hizo acuciante hasta mediados del siglo XIX, pues hasta esa fecha comerciar, en cualquier libro de texto, se consideraba una operación con sus gastos correspondientes que se le debían imputar. De forma implícita, se recurría a la técnica de cargo y abono que había surgido de la relación financiera entre el principal y el agente. Sin embargo, resulta imposible explicar beneficios y gastos en términos de relaciones personales de deuda. Finalmente, se explicaron como partes de la cuenta de capital.

La exposición mediante la personificación de las cuentas sólo fue un aspecto a considerar en el ataque contra el método del Diario en la enseñanza de teneduría de libros con un aprendizaje memorístico apoyado en normas y versificación. Algunos autores de los primeros tratados ya criticaron el sistema de aprendizaje memorístico. Así, Roger North, en The Gentleman Accomptant (1714), dice:

I shall not in this my Understanding, labour very hard, or penetrate deep, by exaggerating Multitudes of Rules and perplexed Examples, as most Writers of this Subject

59 C.F. Sprague, The Bookkeeper, New York, 1882. Citado en A.C. Littleton, Accounting Evolution to 1900, ed. cit., p. 59. 
have done; but in a familiar discursive Way, copy, as it were, my own Sentiments and Reflections, with all the Ease and Freedom, as I suppose one of my own Rank, accountable, as I am, only to himself and his Family, will be content to peruse. And for the Method, I shall here only pre-advertise, that I propose first to give a general Scheme or Description of the Art of keeping Accompts by $\mathrm{Dr}$. and $\mathrm{Cr}$. and then apply it to Practice, as well in the true Writing, as correcting Errors; and subjoin a fictitious Specimen, to render what is discours'd intelligible ${ }^{60}$.

Malachy Postlethwayt, a mediados del siglo XVIII, en su tratado The Merchant's Public Counting-House (1750), especifica su programa para una institución ideal que formase mercaderes. Al referirse a los maestros de teneduría de libros, dice:

... we shall, in a natural progression, proceed to explain systematically the axioms, and rational maxims and principles, whereupon the whole art of accountantship, as practised by the most skilful merchants, according to the method of double-entry, is grounded (...).

This inimitable method of accounts being founded on the principles of reason, will prove a kind of practical logick to young people, when it is rationally and methodically communicated, not mechanically, and by rules depending on the memory only; which latter does not merit the name of instruction at all ${ }^{61}$.

El método memorístico en la docencia de la teneduría de libros era tan frecuente que algunos autores eran reacios a incorporar la materia a su obras. Benjamin Donn, en su ya citado The Accountant and Geometrician (1765) afirma de forma incorrecta:

As book-keeping is a Subject which has not hitherto been inserted in any Course of the Mathematicks, some perhaps may not considerer it as Part thereof (...). But if they would but consider, that, though Book-keeping has commonly been treated of and taught by Way of Rote, or

60 Roger North, The Gentleman Accomptant, ed. cit., pp. 10-11.

61 Malachy Postlethwayt, The Merchant's Public Counting-House: Or, New Mercantile Institution: Wherein is shewn, the Necessity of Young Merchants Being Bred to Trade with Greater Advantages than They Usually Are. With a Practicable Plan for That Purpose. Also Some Remarks on the Benefit of This Institution to the Young Nobility and Gentry, and Such Who Are Intended for the Study of the Law, Second Edition, London: Printed for John and Paul Knapton, in Ludgate-Street, 1751, pp. 24-5. 
arbitrary Rules without shewing the Reason of them; yet as the Subject is of great Utility, is now introduced and taught in all our Acedemies which qualify Youth for Business, requires no inconsiderable Knowledge of Numbers, and in capable of being treated of in a rational Manner ${ }^{62}$.

$Y$, consecuentemente, incluye la teneduría de libros en su tratado de aritmética.

De igual modo se expresa Alexander Malcolm en $A$ New Treatise of Arithmetick and Book-keeping (1718):

Tho' I do not pretend to a New Art, yet I have delivered the Rules of Book-keeping in a new Way. I proposed chiefly to explain and clear the Foundation, and give such Rules and Directions as might make the Practice a Work of Judgement rather than of Memory; every Thing in this excellent Art has a Reason which may, and ought to be shown: I have endeavoured this in laying down the first general Principles, and therefore in the rest I have nothing to do but make every Thing agree to these fundamental Notions, and answer the End; which is either manifest at sight, or I demonstrate it as any Difficulty occurs ${ }^{63}$.

A pesar de todo, aunque los docentes eran contrarios al aprendizaje memorístico, se limitaron a que se razonara la aplicación de las normas; las premisas y la justificación de las mismas no las contemplaron. James Bryce, a modo de ejemplo, en su libro A Treatise of Book-keeping by Double and Single Entry (1860), afirma:

... the learner must exercise his judgement to determine, by the rules, in what book each transaction is to be entered, and how the entry of it is to be expressed. The judicious teacher will perceive the necessity of exercising his pupils in this way, instead of allowing them merely to copy the books ${ }^{64}$.

62 Benjamin Donn, The Accountant and Geometrician, ed. cit., "Preface".

63 Alexander Malcolm, A New Treatise of Arithmetick and Book-keeping..., Edinburgh: Printed by John Mosman and William Brown, for John Paton Bookseller and are to be sold at his Shop in the Parliament-Closs, 1718, "Preface".

64 James Bryce, A Treatise of Book-keeping by Double and Single Entry, Edinburgh: Adam and Charles Black, 1860. 
Con toda probabilidad, la denuncia más nítida de este enfoque la encontramos en Double Entry Elucidated (1852) de B.F. Foster que, a su vez, propone:

The study of book-keeping affords an excellent means of intellectual discipline; that is, when its principles are exhibited, as well as their application -when the reasoning powers are called into exercise, as well as the memory. The student who has carefully attended to the instructions, and who is the master and not the slave of rules, will experience no difficulty in unravelling or adjusting any set of accounts, however complicated or diversified ${ }^{65}$.

\section{VII}

La disputa entre los que eran partidarios del Diario y aquellos que preferían el Mayor como libro de enseñanza, no era otra cosa más que la traducción del conflicto entre el enfoque memorístico y el racional de la teneduría de libros. Los maestros que utilizaban el Diario para presentar la materia estaban condenados a usar las reglas. Los que manejaban el Mayor también podían servirse de las normas, aunque podían desarrollar ciertos principios racionales, si lo estimaban oportuno.

La lucha entre estos dos métodos opuestos suscitó aspectos fundamentales para la docencia de la teneduría de libros. Se resolvió en una batalla entre "antiguos", partidarios del Diario, y "modernos", que preferían el Mayor. El resultado fue la derrota del Diario como Libro principal para la presentación de los principios de la teneduría de libros y quedó relegado a una posición insignificante en la metodología docente. No obstante, esta exclusión no fue solo el resultado de presiones pedagógicas. Su apartamiento lo aceleró el hecho de que el Diario estaba desapareciendo del ámbito de los negocios. Los seguidores del enfoque del Mayor salieron doblemente reforzados: significaba una enseñanza más racional y un cambio en las exigencias de los negocios.

El Diario había dominado la situación durante casi 350 años hasta que, a mediados del siglo XIX, perdió su posición dominante. No

65 B.F. Foster, Double Entry Elucidated, Fifth Edition, London: Printed for John Souter, Published by C.H. Law 131, Fleet Street; Aylott and Jones, 8, Paternoster Row, John Vadenbergh, 161A, Strand, 1852, p. 76. 
obstante, antes de esa fecha ya se habían formulado críticas a la repetición memorística de reglas y a su sistema encorsetado de anotar las partidas.

En la teneduría de libros era corriente que el sistema de aprendizaje, el Plan of Tuition, como dice Philip Comins en The Science of Commerce (1814), consistiera en "to read over and over again, very attentively, the entire of my General Instructions" 66 . Las instrucciones referidas consisten, nada menos, que en doce páginas de letra pequeña. Otra alternativa era que el alumno se condenara a la pesadez de "copying a multitude of similar examples, which gives him employment for some months, before he learns the manner of balancing a single account", según dice R.B. Roe en An Introduction to Book-keeping (1825) ${ }^{67}$.

Theodore Jones, por su parte, en Jone's English System of Book-keeping for Schools (1840), nos dice:

If the learner is not quite master of the subject, after writing up the first Set of Exercises once, he is recommended to write it again and if necessary, repeat it till he has acquired such proficiency as to be able to write up and balance the first set complete ${ }^{68}$.

Siendo justos con los docentes de la época, hemos de recordar que tanto Comins como Jones era hombres de negocios, lo que, por otra parte, era habitual en los enseñantes .

El Reverendo Ebenezer Cobham Brewer, autor prolífico de libros de todas las materias, en An Entire New System of Book-keeping by Single Entry (1850) dice que pretende que sus alumnos copien su libro rellenando los huecos de supuestos prácticos de aritmética. Afortunadamente para los maestros, existía una clave para la resolución de aquellos ${ }^{69}$.

El objetivo de que los estudiantes copiasen ejemplos era mejorar su escritura. Practical Book-keeping Made Easy (1876), de James

66 Philip Comins, The Science of Commerce; or, A New and Universal System of Practical Mercantile Business and Book-keeping Combined, by Double Entry..., Dublin: 1814, p. 30.

67 R.B. Roe, An Introduction to Book-keeping..., London: 1825, "Preface".

68 Theodore Jones, Jone's English System of Book-keeping for Schools, London: Published by Theodore Jones \& Co., 8, Moorgate Street, 1840, p. 2.

69 The Rev. Dr. Brewer, An Entire System of Book-keeping by Double Entry: Compiled from Invoices by London Merchants and Adopted to Modern Practice for the Use of Schools and Private Tuition, London: Jarrold and Sons, 47, St. Paul's Churchyard, 1850. 
Dimelow, es el mejor ejemplo de este tipo de enfoque. Sus páginas son pliegos con una bonita letra inglesa en la parte izquierda que tiene que copiarse en la derecha ${ }^{70}$.

La clase de teneduría de libros que se enseñaba y la metodología no satisfacía a nadie más que a los maestros. En una recensión de Double Entry Elucidated, de B.F. Foster, que The Times publicó el 17 de octubre de 1845, leemos:

"There needs little observation to know that the manner in which merchants' accounts are taught in the generality of schools is tedious, defective, and unsatisfactory. The pupil is disgusted, because the systems adopted are incomprehensible, or so perplexed with difficulties that the reason is fettered, and all attempts at deductions from the premises are futile, and so much labour lost. Now Mr. Foster teaches book-keeping -not by drilling the learner into a calculating machine, but by enabling him to reason upon and comprehend what he is doing, or about to do. The science is laid down with clearness and perspicuity; the rules are plain, comprehensible and unerring; and the whole is illustrated by examples, so that any person of common capacity may understand the system, and be able to unravel any set of accounts, however complicated, or to keep his own or his employer's books in a satisfactory manner" -The Times; Oct. $17,1845^{71}$.

El factor decisivo en la sustitución del Diario por el Mayor como libro principal para la presentación del sistema está en que, a principios del siglo XX, el Diario como libro único de registro cronológico, en la práctica, había dejado de existir. Con independencia de su valor educativo, no debemos olvidar que la teneduría de libros tiene un fundamento profesional y si este cambia de forma, entonces la estructura general también debe hacerlo.

Además de las razones profesionales, cabría preguntarnos por la base pedagógica que se utilizó para preferir el Mayor al Diario. Digamos, brevemente, que las partidas del Diario eran registros con los

70 James Dimelow, Practical Book-keeping Made Easy. A Series of Practical Bookkeeping, Including An Entirely New Mode of Teaching It (...) for the Use of Commercial Schools and for Self-Tuition, London \& Glasgow: William Collins, Sons \& Co., 1876.

71 Citado en B.F. Foster, The Origin and Progress of Book-keeping, ed. cit., p. 51. 
que no se podía tomar ningún tipo de decisión hasta comprender el efecto que ejercían en el Mayor. Las partidas del Diario, en realidad, eran las partidas del Mayor en estilo técnico. Y el intento de dejar los tecnicismos de la materia a un lado fue lo que condujo al declive del uso del Diario como medio pedagógico. B.F. Foster en su tratado de didáctica -probablemente el primero-, de la teneduría de libros, Counting-House Instruction. Remarks on the Ordinary Modes of Teaching Writing and Book-keeping (1846), dice:

The ordinary mode of teaching book-keeping is to commence by copying from some popular treatise a series of transactions, such as receipts, payments, purchases, sales, consignments and the like. After being wearied, secundum artem, with this work, the student is made to construct a journal; that is, to narrate under what heads in the ledger the respective items are to be placed, the substance of his instruction being, that "the thing received is debtor to the thing delivered"; but as to the object of making one thing debtor to another, he must be totally ignorant; for every journal entry has reference to the ledger, and the ledger is a sealed book to him. His whole progress through the journal is, therefore, a blind process of guessing; and when, ultimately; he transfers these items to the ledger, and balances his books, he does so more like an automaton than a rational being ${ }^{72}$.

$\mathrm{Y}$, de forma más directa, lo vuelve a repetir en su Double Entry Elucidated (1852) cuando advierte de que es imposible entender los tecnicismos del Diario, salvo que se conozca la estructura y uso de cada cuenta del Mayor; de ahí que -prosigue-, el Mayor deba ser el primero y no el último libro que se debe revisar.

Con anterioridad ya se había producido un ataque similar al enfoque del Diario en Estados Unidos con Thomas Jones a la cabeza. El Profesor Littleton en su libro Accounting Evolution to 1900 cita una carta que B.F. Foster dirigió a Thomas Jones en la que le concede el honor de haber generado el método que comienza la explicación teórica con el Libro Mayor ${ }^{73}$.

Pero la apreciación de la supremacía del Mayor en la enseñanza no fue un descubrimiento casual de mediados del siglo XIX. Así,

72 B.F. Foster, Counting-House Instruction. Remarks on the Ordinary Modes of Teaching Writing and Book-keeping, London: 1846, p. 4.

73 A.C. Littleton, Accounting Evolution to 1900, ed. cit., p. 181. 
Alexander Malcolm, en su ya mencionado A Treatise of Bookkeeping, or, Merchants Accounts (1731), considera que el Libro Mayor es el más importante de todos los libros de cuentas. Sin embargo, en la didáctica, el Mayor no adquirió esa carta de naturaleza hasta el siglo XIX.

James Morrison fue uno de los primeros en advertir de su importancia en The Elements of Book-keeping (1813):

... we shall next consider the Ledger, because, though the Journal comes before it in the order of writing yet the Journal cannot be well understood until the nature of the Ledger be explained ${ }^{74}$.

Sin embargo, hasta que el Profesor de Morgan se adhirió a la "escuela del Mayor", no se produjo una verdadera proliferación de libros que utilizan este enfoque. La importancia que de Morgan concede a la naturaleza de la teneduría de libros por partida doble con la personificación de las cuentas, le llevó a adquirir una autoridad académica que le permitió decir que

The only book that need be explained is the ledger. All the other books, and the manner in which they are kept, important as they may be, have nothing to do with the main principle of the method ${ }^{75}$.

No debemos olvidar que el anejo de de Morgan sobre teneduría de libros no se publicó hasta 1846 y no fue ampliamente conocido hasta su siguiente edición, treinta años más tarde. Durante este interregno de tres décadas sólo hemos logrado localizar un tratado que utilice el enfoque del Mayor. Se trata de la obra de Henry Manly, "Principal WritingMaster and Teacher of Book-keeping in the City of London School", The Principles of Book-keeping by Double Entry $(1864)^{76}$. Pero después de 1876 el ritmo de aparición de tratados se hizo más rápido. First Lessons in Book-keeping de J. Thornton, que ya hemos mencionado, se publicó en 1879

74 James Morrison, The Elements of Book-keeping by Single \& Double Entry. Comprising Several Sets of Books. Arranged According to Present Practice \& Designed for the Use of Schools. To Which is Annexed An Introduction on Merchants Accounts with Engraved Specimens, London: Printed for Longman, Hurst, Rees, Orme, Brown \& Green, 1813, p. 20.

75 Augustus de Morgan, Elements of Arithmetic, ed. cit., p. 181.

76 Henry Manly, The Principles of Book.keeping by Double Entry, in A Series of Easy and Progressive Exercices, London: Edward Stanford, 6, Charing Cross, S.W., 1864. 
y Elementary Book-keeping, de George Lisle, en $1894^{77}$. Ambos muestran todas las operaciones a través del Mayor antes de ocuparse del Diario.

En la década de 1890 la cuestión fue cobrando interés y el nombre de de Morgan se cita frecuentemente. En efecto; E.E. Whitfield lo menciona en su obra Introduction to the Commercial Sciences (1900):

The disrepute into which Book-keeping as a school subject had fallen down to a recent period is traceable to the mistaken postponent of work upon the ledger to the detail consideration of other books of account. Professor De Morgan showed that it is in ledger work that the main principle is learnt ${ }^{78}$.

Andrew Sarll, por su parte, en Double Entry Book-keeping in Theory and Practice (1881) también utiliza el enfoque del Mayor, con lo que, a principios del siglo $X X$, este método de presentación era suficientemente conocido en los círculos docentes ${ }^{79}$.

VIII

Hasta el siglo XIX, como hemos visto, la racionalización más importante de las partidas de teneduría de libros fue la personificación de cuentas. No obstante, tan solo es una de las teorías que influyó en el método de exposición. Una teoría alternativa es la que podemos denominar teoría de la propiedad de las cuentas y que se ocupa del significado de estas desde el punto de vista del propietario.

Desde una perspectiva técnica, la teoría de la propiedad de las cuentas conlleva un balance de situación o un enfoque de ecuación de balance porque el objeto de atención y el punto de partida y de llegada es el balance de situación. Esto supone un cambio radical respecto al concepto de relación de deuda de las cuentas en el que el balance de situación es el resultado final de las anotaciones en cuenta. Por el

77 George Lisle, Elementary Book-keeping in Theory and Practice. With Numerous Examples and Exercises, Together with Solutions, London \& Edinburgh: W. \& R. Chambers, Limited, 1894.

78 E.E. Whitfield, Introduction to the Commercial Sciences, London: Rivingtons, 34, King Street, Covent Garden, 1900, pp. 118-9.

79 Andrew Sarll, Double Entry Book-keeping in Theory and Practice; Illustrated by Short and Graduated Exercices; Followed by Examination Papers Arranged in Order of Their Difficulty..., London: George Gill \& Sons, Ltd., Warwick Lane, Paternoster Row, 1899, [1881]. 
contrario, en el caso de la teoría de la propiedad, el balance de situación se concibe más como un mecanismo activador que como objetivo último. Se trata del desarrollo lógico para configurar un ciclo de operaciones. Se considera el balance de situación como la cristalización de la posición financiera del negocio. En lugar de detallar todos los efectos de las operaciones en el balance de situación, como en el método "cíclico", se analiza la transacción con el fin de determinar los cambios que supondrá en la estructura financiera. Lo que será el nuevo balance de situación y las anotaciones en cuenta se formula como resultado de este análisis. Es un enfoque completamente diferente. La atención no se centra en el "intercambio" entre cuentas sino en las transformaciones de cada lado del balance de situación. Se analizan las transacciones en términos de mutación de activos y pasivos de la empresa y sus efectos en el beneficio de la propiedad. La argumentación discurre en términos de conversión más que de relación de deuda; de relación estadística impersonal más que de relación personal; de análisis más que de norma y memoria. Las cuentas son crecientes o decrecientes en vez de abonarse o cargarse. La atención pasa de la ficción a la realidad de la teneduría de libros.

El origen de la teoría de la propiedad, en esencia, se encuentra en el tratado de Hustcraft Stephens, Italian Book-keeping Reduced Into an Art $(1735)^{80}$.

Stephens consiguió salir del embrollo de la personificación en un momento en el que no se conocía, ni se contemplaba, ninguna otra alternativa. Su enfoque era tan novedoso que se vio obligado a acuñar nuevas palabras para expresar sus ideas. Desde una perspectiva docente, su método de exposición se adelantó un siglo en emanciparse de las reglas. El plan de la obra lo recoge en el Prefacio:

For as the treats of Italian Book-keeping after a Manner so intirely New, it were unreasonable to expect that He should confine Himself to any particular Terms or Forms dogmatically prescribed by others; when his Design is to offer no Rules, until he has shewn them to be the Consequences of Conclusions, plainly drawn from Selfevident Principles, or what are previously demonstrated

80 Hustcraft Stephens, Italian Book-keeping Reduced Into an Art: Being an Entire New and Compleat System of Accompts in General. Demonstrated in a Chain of Consequences from Clear and Self-Evident Principles. To Which is Added, The Greatest Variety of Merchants Accounts, with an Explanation of All the Terms of Art, Which have Commonly Been Madre Use of. Together with Proper Reflections on the Whole, London: Printed for W. Mears, at the Lamb on Ludgate-Hill, 1735. 
from such; and to make Use of no Terms in a different Sense from the common Acceptation, until He has first sufficiently explain'd them, and given His Reason for it ${ }^{81}$.

En su Introducción pone los cimientos de su teoría de la mutación de activos y pasivos definiendo el capital como un ente independiente de la empresa:

That Portion of Things which a Man possesses, or has otherways belonging to him, as a Security, taken all together, I call the Estate, and the Worth of a Man's Estate, consider'd abstractly from the Things which are valued, I call the computed Value or Extent of a Man's Estate $^{82}$.

Por lo general, utiliza el término Condition para lo que hoy denominamos activos (assets) y Extent para los pasivos (liabilities). Ambas palabras poseen una carga semántica especial debido a la inexistencia de términos apropiados. Y, con sencillez, expresa la finalidad de la teneduría de libros:

$\ldots$ it is indispensably required of every prudent Man to know exactly the computed Value and Condition of his Estate, in order to the well governing himself in the Management of his worldly Affairs: for without that Knowledge, he cannot make any one Step in them with Certainty; but must grope blindly in the Dark, and by Chance sink or swim; which is a Hazard no wise Man would willingly trust his Fortune to ${ }^{83}$.

El paso siguiente es la clasificación de las transacciones en tres categorías, dependiendo de la forma en la que puedan afectar a activos, a pasivos, o a ambos al mismo tiempo. Igualmente introduce la idea, novedosa para su época, de que el propietario es un acreedor del negocio. En efecto; resulta interesante observar que la palabra propietario (proprietor) se utiliza con el sentido que hoy damos a acreedor (creditor), lo que indica que Stephens concebía el lado del pasivo del balance de situación como componente natural de una lista de fuentes o recursos,

\footnotetext{
81 Ibid., "Preface", p. vi.

82 Ibid., "The Introduction", p. 2.

83 Ibid., "The Introduction", p. 4.
} 
con lo que se aparta del concepto de teneduría de libros de mero registro de relaciones de deuda.

La explicación de Hustcraft Stephens de la función de las cuentas demuestra una perfecta comprensión de su uso como herramienta aritmética para mostrar las variaciones de activos y pasivos individuales:

I say, the various Securities must be so divided, that when by any Transaction it becomes necessary to add to, or taken from the respectively any Quantity, Number, or Sum, we may do it so, that the remaining Quantity, Number, or sum, with the Alterations that produced them, may appear: for which Reason there must be a competent Space allow'd each Division (wherein the first Quantities, Numbers, or Sums are noted) for the Recital of the Alterations of adding to, or taking from, as Occasions offer ${ }^{84}$.

Más adelante muestra los efectos de compras, ventas, ingreso y pago en metálico en la posición financiera del negocio. Por ejemplo: la venta de 500 libras de azúcar a 50 libras y la compra de 3000 a 150 se sustancia del siguiente modo:

Second Account.

Sugar bears Part of the Condition of my State. I have $1000 \mathrm{lb}$. for

Alter. I. Sold out $500 \mathrm{lb}$. for l. s. d. $\begin{array}{lll}100 & 0 & 0\end{array}$

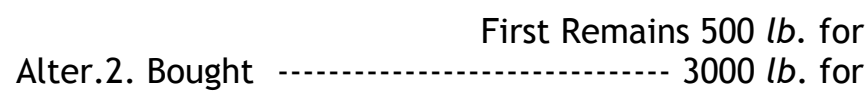
$\begin{array}{lll}50 & 0 & 0\end{array}$ Second Remains $3500 \mathrm{lb}$. for 20000

Third Account.

Money bears Part of the Condition of my Estate. I have 200000

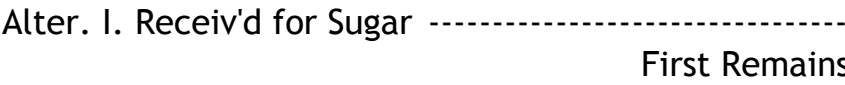

Alter.2. Bought Sugar; for which I paid 
Las sumas y restas constantes son tediosas, ... whereas, were all these Alterations which cause an Increase of the Condition, and those which likewise bear a Part of the Extent, respectively gather'd together, they might at Pleasure be compar'd by one Substraction after their Sums were severelly added up ${ }^{86}$.

Y de este modo, llegamos a la forma habitual de la cuenta con dos lados.

El tratado de Stephens significa un distanciamiento total de la explicación imperante: la personificación. Los autores que le sucedieron no lo mencionan y sus conceptos no se desarrollaron durante setenta y cinco años; pero ya se disponía de un marco para un enfoque impersonal y estadístico, con una exposición completa de la función aritmética de la cuenta. Ahí es donde reside el valor de la aportación de Stephens al método docente.

Esta visión de la estructura de las cuentas no volvió a ser abordada hasta el inicio del siglo XIX. John Williamson Fulton, "Bookkeeper in the Office of the Accountant to the Board of Revenue, Bengal", había comprobado que era bastante dificil obtener una visión general rápida de la situación financiera personal o del negocio con los métodos existentes de teneduría de libros. En consecuencia, el objetivo de su libro British-Indian Book-keeping era exponer un método de llevar las cuentas que reflejara "the progressive effect of all transactions on the General Stock daily or monthly, according as the entries and adjustments are made"87. Teniendo presente su objetivo, había captado un aspecto importante de la teoría de la propiedad en contabilidad: que las cuentas constituyen un método para registrar cambios en los activos y pasivos de la persona o de la compañía y que todos estos cambios deben reflejarse en el balance de situación.

Fulton destaca que, en esencia, únicamente es necesario distinguir entre la cuenta de capital y el resto, porque

86 Ibid., p. 13.

87 John Williamson Fulton, British-Indian Book-keeping. A New System of Double Entry and Progressive Adjustment; Exemplified in a Variety of Compendious Methods, for the Practical Purposes as well of the Private Gentleman as of the Merchant. The whole Calculated to Supply a Desideratum in the Art, by a Perspicuous Process, never before adverted to..., London: Printed by G. Auld, Greville-Street, Hatton-Garden, and Sold by Vernor \& Hood, Poultry, 1800, p. vi. 
... the stock account is that of the principal (...) of a concern: it is not composed of a particular independent property $(d)$, like each of the other accounts, but arises from the state of all these collectively taken, which thus form merely the particulars of it: and the grand aim of double entry is, to ascertain the true state of the account (...) and to check the balance thereof, by the net balance collectively of all the other accounts ${ }^{88}$.

Y prosigue señalando que la igualdad de cargos y abonos no se ve entorpecida:

If a gain be made, $\mathrm{Cr}$. side of the stock account is thereby increased, and of course the whole Cr. line; but at the same time the Dr. side of cash or some other, one or more, accounts must be equally increased. A loss will increase the Dr. side of stock, and increase in an equal degree the $\mathrm{Cr}$. side of some other account or accounts. In buying and selling, receiving and paying, drawing and remitting, bartering \& c. this equality, in the amount of the respective Drs. and Crs. affected by each of these various transactions, will still be found to hold good; so that the extension or diminution of the two lines in question must ever be equal in regard to each other ${ }^{89}$.

Reconoce y destaca que el saldo de la cuenta de capital no es únicamente la diferencia entre activos y pasivos, sino también el saldo original junto con el efecto neto de los cambios que se derivan de pérdidas y ganancias. Mediante columnas adicionales en su Diario, Fulton, al distinguir entre partidas de capital e ingresos, puede analizar el efecto neto sobre el capital de todas las transacciones para así extraer el saldo neto de capital en cualquier momento y equipararlo con el efecto neto de cambios en otros saldos de cuentas. Con independencia del valor práctico de su aportación, la obra de Fulton supone un paso más en la nueva forma de considerar el objetivo de la teneduría de libros y las interrelaciones entre las cuentas del Libro Mayor. 
Dieciocho años después de la publicación del tratado de Fulton, la exposición de la teoría de la propiedad la completó F.W. Cronhelm con su libro Double Entry by Single $(1818)^{90}$.

La contribución de Cronhelm se sustancia en su enunciado del capital como un "todo"; su diferenciación de las partes que lo constituyen y el inevitable "equilibrio" del todo con las partes. Su enfoque es matemático, aunque tiene algunos lapsus de personificación.

Cronhelm, lo mismo que Stephens y Fulton, considera la teneduría de libros como un método para registrar la propiedad y los cambios que en ella se producen, más que relaciones de deuda:

The purpose of Book-keeping, as a record of property, is to shew the owner at all times the value of his whole capital, and of every part of it. The component parts of property in trade, are in a state of continual transformation and change; but whatever variations they undergo, and whether the whole capital increase, diminish or remain stationary, it is evident that it must constantly be equal to the sum of all its parts. This EQUALITY is the great essential principle of Book-keeping ${ }^{91}$.

Desde esta perspectiva, ninguna cuenta puede considerarse ficticia o imaginaria. Todas son reales; y buena parte de la confusión que se había suscitado con la teoría de la personificación, desaparece. Con el rechazo de la personificación se abría el camino para un enfoque matemático abstracto:

The introduction of Credit and Bills into commerce, produced two kinds of property directly contrary in their natures:

1st, Positive Property, consisting of Goods, Cash, Bills Receivable, and Debts Receivable.

2d, Negative Property, consisting of Bills Payable, and Debts Payable.

And as these two kinds of property mutually destroy each other, it is evident that the Stock, or entire capital,

90 F.W. Cronhelm, Double Entry by single, A New Method of Book-keeping, Applicable to All Kinds of Business; and Exemplified in Five Sets of Books, London: Printed for the Author by Bensley and Sons, Bolt-Court, Fleet Street; and Published by Longman, Hurst, Rees, Orme, and Brown, Paternoster-Row, 1818.

91 Ibid., p. vi. 
must always be equal to the difference between them, and be of the same nature as that which preponderates.

Hence arise three varieties of Stock or Property; the Positive, the Neutral, and the Negative; in the first two of which the proprietor is solvent, in the latter, insolvent ${ }^{92}$.

Desde la idea de la cuenta de capital, como herramienta de equilibrio matemático, lógicamente se infiere que debe ser una partida de abono:

Should it be inquired why the Stock appears to be negative when the property is positive, and positive when the property is negative, this seeming contradiction will be removed by the following consideration. In these general relations of Debtors and Creditors, the estate or concern itself is abstracted from its proprietor, and becomes a whole, of which the Stock or proprietor's Account is now also of the component parts. If, therefore, his property be positive, the Concern is Debtor to him for that property, the same as to any other person; and he classes among its other Creditors. If, on the other hand, his property be negative, or himself insolvent, the Concern is Creditor, and he classes among the other Debtors ${ }^{93}$.

Además de la cuenta de capital, todas las demás son factores de equilibrio:

... when we thus abstract a Concern from its Proprietor, and place the account of Stock or entire capital among the component parts, the Concern itself is constantly neutral, consisting of a mass of relations between Debtors and Creditors, in perpetual and necessary equilibrium. The Concern thus abstracted, is always a cypher; and all its component parts are equally and mutually dependent upon each other, and upon the whole. It is no longer merely the Stock which is the result of all the other Accounts collected together: every Account has the same property, and may be found or proved in the same manner ${ }^{9}$.

Y expresa el mismo razonamiento en forma algebraica:

\footnotetext{
92 Ibid., p. 5.

93 Ibid., pp. 7-8.

94 Ibid., p. 8.
} 
Let $a, b, c \&$ c. represent the positive parts, or Debtors; $l, m, n \& c$. the negative parts, or Creditors; and $s$ the Stock, or proprietor's real worth. Then as the whole is equal to the sum of its parts,

$$
a+b+c, \& \text { c. }-l-m-n, \& \text { c. }= \pm s \text {. }
$$

By transposition we obtain

$$
a+b+c, \& \text { c. }-l-m-n, \& \text { c. } \mp s=0,
$$

or that general equation, in which the whole Estate is neutral or a cypher, and includes the Stock as one of its component parts. Hero too, it may be observed that the transposition of $s$ changing its sign, explains the reason why the Stock, when positive in itself, becomes negative or creditor as a component part of the estate, and positive or debtor when negative.

Again, by transposing any one of the terms in the general equation, it may be proved to be equal to all the rest. Thus,

$$
\begin{gathered}
\quad b+c, \& \text { c. }-l-m-n, \& \text { c. } \mp s=-a ; \\
a+b+c, \& c .-m-n, \& \text { c. } \mp s=l ; \\
a+b+c, \& c .-l-m-n, \& \text { c. }= \pm s .
\end{gathered}
$$

Hence the truth of that general proposition already laid down, that any debtor or creditor in the books is equal to the collective result of the other debtors and creditors, an affection which has been commonly supposed peculiar to the stock account ${ }^{95}$.

Esta ecuación general, no obstante, es un concepto estático y cuando se realizan las transacciones se requiere una exposición de formas dinámicas. Las partes que las componen están en constante fluctuación. Para ello Cronhelm desarrolla una teoría de la propiedad que considera la transformación de una clase de propiedad en otra:

The component parts of property in trade are in a state of continual fluctuation and change. In purchases, cash is converted into goods; and in sales, goods are reconverted into cash. Or, if credit allowed, the changes

95 Ibid., pp. 8-9. Resulta sorprendente que esta idea de una ecución fundamental no la desarrollaran los matemáticos. Pierre Jocet escribió su tratado Théorie algébrique et idéologique de la tenue des livres en 1898 y desarrolló una estructura de ecuaciones partiendo de su équation fondamentale, que tiene muchas semejanzas con la de Cronhelm. Cfr. Charles H. Griffin and Thomas H. Williams, "A Comparative Analysis of Accounting and Mathematics", Accounting Review, 37 (No. 3, Jul., 1963), pp. 410-4. 


\begin{abstract}
are still more numerous. Purchases create personal creditors and goods; sales convert goods into personal debtors; receipts convert personal debtors into cash; whilst payments destroy cash and personal creditors. The introduction of bills would multiply the changes by an intermediate stage between personal debts and cash. But all these creations, metamorphoses, and destructions of the parts, resolve themselves into the single case, that in every transaction two accounts are affected, the one receiving what the other communicates. The imparting account is always creditor, and the recipient always debtor; so that in each occurrence debtor and creditor must perfectly equilibrate ${ }^{96}$.
\end{abstract}

Y prosigue aplicando el sistema a las pérdidas y ganancias, considerándolas aumento o disminución del capital. La función de la cuenta de pérdidas y ganancias es, pues, una especie de método para agrupar todos los aumentos o disminuciones individuales de capital, con lo que el resultado general se puede transferir, en una cantidad total, a la cuenta de capital.

Por todo lo dicho, los principios básicos de la teoría de la propiedad ya estaban expuestos, de modo sencillo y claro, en 1818. Esos principios suponían la separación radical de propietario y negocio; la ecuación fundamental de la propiedad; y el concepto de transacción que afecta a esta ecuación, según aumenten o disminuyan los activos, pasivos o el capital. Este método de explicar y enseñar la teneduría de libros desapareció de las aulas británicas, aunque a lo largo del siglo XIX siguieron apareciendo tratados que se fundamentan en la teoría de la propiedad. Ese es el caso de A New System of Book Keeping (1828) de P.C.L. Vautro97; The Perfect Book-keeper (1849), de J.H. Chauvier ${ }^{98}$; A Treatise on Book-keeping (1867), de R.Y. Barnes ${ }^{99}$; o Book-keeping and Accounts (1891), de Percy Child ${ }^{100}$, ya al borde del siglo XX.

96 Ibid., p. 9.

97 P.C.L. Vautro, A New System of Book Keeping; Calculated to Promote the Neccessary Reform of the Old Methods, by Following the Means Particularly Recommended by the Best English Authors, London: Printed for the Author; and Sold by S. Salvá, 124, Regent Street, Boosey and Sons, 4, Old Broad Street; and J. Richardson, 91, Royal Exchange, 1828.

98 J.H. Chauvier, The Perfect Book-keeper, A New Method of Book-keeping, by Double Entry..., London: 1849.

99 R.Y. Barnes, A Treatise of Book-keeping; Showing the Advantages of a Clear, Distinct, and Accurate Method of Accounts; and Explaining the Principles of a New and Improved System, Adapted to Meet the Wants of the Entire Trading Community; and by the Use of Which 
El rasgo sorprendente de este enfoque, despersonalizado y matemático, de la teneduría de libros es que, aunque fue el método habitual en Estados Unidos y en algunos países europeos, tuvo que esperar hasta 1949 para ser incorporado a los libros de texto británicos.

Aun es pronto para hacer una valoración de lo sucedido en la docencia de la teneduría de libros en Gran Bretaña, a lo largo del siglo XX.

Goethe, por boca de uno de sus personajes, declaró que la partida doble es una de las invenciones más bellas de la mente humana. Seguro que no se imaginó que iba a ser objeto de controversias de concepto, de desarrollo de método didáctico, de sistemas de aprendizaje y de competencia. Después de todo y como en todo, la invención bella ha pasado por los filtros de las artes y de las ciencias, salvaguardando, claro está, un principio siempre respetado por todos: business is business.

\section{BIBLIOGRAFÍA}

BARNES, R.Y. (1867) A Treatise of Book-keeping; Showing the Advantages of a Clear, Distinct, and Accurate Method of Accounts; and Explaining the Principles of a New and Improved System, Adapted to Meet the Wants of the Entire Trading Community; and by the Use of Which Perfect Bookkeeping May Be Obtained in All Businesses, Small as well as Large, with Ease and Profit. London: John Haddon \& Co.

BOUTLER, Geo H. (1847) A Course of Bookkeeping by Double and Single Entry, As Applied to Inland and Foreign Trade, Containing the Most Recent Improvements Both in the Method of Teaching, and in the Practice of the Art. Adapted to the Use of Schools or Self-Instruction. London: John Mabley.

BREWER, The Rev. Dr. (1850) An Entire System of Book-keeping by Double Entry: Compiled from Invoices by London Merchants and Adopted to Modern Practice for the Use of Schools and Private Tuition. London: Jarrold and Sons.

BROWNE, Thomas (1670) The Accurate Accomptant or London-Merchant.... Also a Journal and Leager.... With An Addition of An Accompt Partable,

Perfect Bookkeeping May Be Obtained in All Businesses, Small as well as Large, with Ease and Profit, London: John Haddon \& Co., 3, George Yard, Lombard Street, 1867.

100 Percy Child, Book-keeping and Accounts, London: R.E. Thomas and Co., 24, White St., Finsbury, E.C., 1891. 
Wherein Four Persons Are Mentioned to Joyn in Partnership Upon Two Several Designs: in Both Which, They All Have Different and Unequal Parts. With A Question Concisely Stated And Resolved.... London: William Godbid for John Hancock.

BryCE, James (1860) A Treatise of Book-keeping by Double and Single Entry. Edinburgh: Adam and Charles Black.

BUINGHA, Johannes (1627) Oprecht Fondament Ende principalen inhout van het Italiaens Boeck-houden. Om van alle Partyen den Rechten Debiteur, ende Crediteur te stellen, die selve int cort op t'groot Boeck, over te draghen: Mitsgaders een grontlijcke onderrichtinghe, om een y eghelijcx Reeckeninghe in Debito, ende Credito van t'groot Voeck wel te verstaen, zijride t'voornaemste des Boeck-houdens. t'Amstelredam: Willem lansz, Stam Boeckvercooper.

CARPENTER, I. (1632) A Most Excellent Instruction for the Exact and Perfect Keeping Merchants Bookes of Accovnts, By Way of Debitor and Creditor, after the Italian Manner: Most Vsefvll for all Merchants, Factors, And Tradesmen.... London: I.B. for lames Boler.

ChAUVIER, J.H. (1849) The Perfect Book-keeper, A New Method of Bookkeeping, by Double Entry.... London.

CHILD, Percy (1891) Book-keeping and Accounts. London: R.E. Thomas and Co.

COLLIER, James (1884) Bookkeeping by Double Entry: Familiarly Explained Together with Copious and Graduated Exercises, and a New Method for Dealing with Small Debts. London: Relfe Brothers.

ColLINS, John (1653) An Introduction to Merchants Accounts Containing Five Distinct questions of Accounts.... London: James Flesher for Nicholas Bourn.

Comins, Philip (1814) The Science of Commerce; or, A New and Universal System of Practical Mercantile Business and Book-keeping Combined, by Double Entry.... Dublin.

CRELLIN, Philip (1892) Bookkeeping for Teachers and Pupils With Accounts in Illustration, Exercices for Practice and A Glossary of Commercial Terms. London: Whittaker \& Co.

CRONHELM, F.W. (1818) Double Entry by single, A New Method of Bookkeeping, Applicable to All Kinds of Business; and Exemplified in Five Sets of Books. London: Longman, Hurst, Rees, Orme, and Brown.

DAFFORNE, Richard (1635) The Merchants Mirrour: Or Directions for the Perfect Ordering and Keeping of His Accounts; Framed by way of 
Debitor and Creditor, after the (so termed) Italian-manner: containing 250 Rare Questions, with their Answers, in forme of a Dialogue. London: R. Young.

DAFFORNE, Richard (1670) [1640] The Apprentices Time-Entertainer Accomptantly: Or A Methodical means to obtain the Exquisite Art of Accomptantship: Digested in Three Parts.... London: W. Godbid.

DE MORGAN, Augustus (1876) Elements of Arithmetic, Sixth Edition. London: Edward Stanford.

DÉGRANGE, Edmond (1806) La tenue des livres rendue facile, ou nouvelle méthode d'enseignement à l'usage des personnes destinées au commerce, avec une nouvelle méthode pour tenir des livres en double partie, par le moyen d'un seul registre dont tous les comptes balancent journellement. Sixtième édition, revue, cossignée et augmentée. Paris: Hocquart \& Bordeaux, chez l'auteur et chez Filiatre [\&] de l'imprimerie de J. Foulquier.

Dimelow, James (1876) Practical Book-keeping Made Easy. A Series of Practical Book-keeping, Including An Entirely New Mode of Teaching It (...) for the Use of Commercial Schools and for Self-Tuition. London \& Glasgow: William Collins, Sons \& Co.

DonN, Benjamin (1765) The Accountant and Geometrician: Containing the Doctrine of Circulating Decimals, Loga rithms, Book-keeping and Plain Geometry.... London.

DYER, S. (1897) A Common Sense Method of Double-Entry Bookkeeping on First Principles. As Suggested by De Morgan, 2 vols.. London: George Philip \& Son.

FOSTER, B.F. (1846) Counting-House Instruction. Remarks on the Ordinary Modes of Teaching Writing and Book-keeping. London.

- (1852) Double Entry Elucidated, Fifth Edition. London: John Souter.

- (1852) The Origin and Progress of Book-keeping: Comprising an Account of All the Works on This Subject, Published in the English Language, from 1543 to 1852, with Remarks, Critical and Historical. London: John Souter.

FULTON, John Williamson (1800) British-Indian Book-keeping. A New System of Double Entry and Progressive Adjustment; Exemplified in a Variety of Comprendious Methods, for the Practical Purposes as well of the Private Gentleman as of the Merchant. The whole Calculated to Supply a Desideratum in the Art, by a Perspicuous Process, never before adverted to.... London: G. Auld. 
GRIFFIN, Charles H. and Thomas H. WiLlams (1963) "A Comparative Analysis of Accounting and Mathematics", Accounting Review, 37 (No. 3, Jul.), pp. 410-4.

HAMILTON, R. (1788) A Short System of Arithmetic and Bookkeeping. With A Supplement; Containing Answers to the Arithmetical Questions. London: C. Elliot \& T. Kay and Edinburgh: C. Elliot.

HAMILTON, R.G.C. and John BALL (1869) Book-Keeping. Oxford: At the Clarendon Press.

HAMILTON, Robert (1777) An Introduction to Merchandize. Containing A Compleat System of Arithmetic. A system of Algebra. Book-keeping in various forms. An Account of the Trade of Great Britain, and the Laws and Practices which Merchants are Chiefly Interested In, 2 vols., Edinburgh: Printed for the Author.

HATTON, Edward (1707) [1701] The Merchant's Magazine: or, Trade Man's Treasury.... London: E.M. for Chr. Coningsby.

HAYES, Richard (1731) Modern Book-keeping, or, the Italian Method Improved; Containing Rules and Directions for Keeping... Accompts by Double Entry. London.

[JONES, Edward Thomas] (1796) Jone's English System of Book-keeping by Single or Double Entry, in Which It Is Impossible for an Error of the Most Trifling Amount to Be Passed Unnoticed; Calculated Effectually to Prevent the Evils Attendant on the Methods so Long Established; And Adapted to Every Species of Trade.... Bristol: R. Edwards.

JONES, Theodore (1840) Jone's English System of Book-keeping for Schools. London: Theodore Jones \& Co.

KATS, P. (1926) "Hugh Oldcastle and John Mellis", The Accountant, LXXIV (27 March), pp. 483-487.

KeLlY, P. (1801) The Elements of Bookkeeping; Comprising a System of Merchants Accounts, Founded on Real Business, and Adapted to Modern Practice: With An Appendix on Exchanges, Including the Recent Alterations. Edinburgh.

KING, Thomas (1717) An Exact Guide to Book-keeping by Way of Debtor and Creditor: Done After the Italian Method.... London: S. Cruttenden.

Lanero Fernández, J. y E. ORTEGa MONTES (2006) "Algunas consideraciones historiográficas sobre la lógica de la Partida Doble y la clasificación de Cuentas", Pecvnia, 2, pp. 65-78. 
LANERO FERNÁNDEZ, Juan (2004) El esplendor de la teneduría de libros: la partida doble en los tratados contables ingleses de la dinastía Tudor (1543-1588). Tesis Doctoral, Universidad de León.

LEWIS, James Henry (1869) The Quick and Easy Method of Teaching Bookkeeping According to the English, Italian, and Scotch Systems of Single Entry and Double Entry Exemplified in Individual and Partnership Accounts, Both Domestic and Foreign. Forming a Branch of The Royal Lewisian System of Commercial Education. London: Printed for the Author and Sold at His Only Institution.

LISLE, George (1894) Elementary Book-keeping in Theory and Practice. With Numerous Examples and Exercises, Together with Solutions. London \& Edinburgh: W. \& R. Chambers, Limited.

LITTLETON, A.C. (1966) [1933] Accounting Evolution to 1900, New York: Russell \& Russell.

MALCOLM, Alexander (1718) A New Treatise of Arithmetick and Bookkeeping.... Edinburgh: John Mosman and William Brown.

- (1731) A treatise of Bookkeeping, or, Merchants Accounts; in the Italian Method of Debtor and Creditor.... The Whole Illustrated and Exemplified with Two Sets of Books, Containing Great Variety of Practice in All those Branches of Business. London: J. Osborn and T. Longman.

MANLY, Henry (1864) The Principles of Book.keeping by Double Entry, in A Series of Easy and Progressive Exercices. London: Edward Stanford.

MANZONI, Domenico (1540) Qvaderno Doppio col svo giornale, novamente composto, \& diligentisimamente ordinato, secondo il costume di Venetia. Opera a ogni persona utilissima, \& molto necessaria. Cvm gratia et privilegio del llustrissimo Senato di Venetia, per Anni diece.

MATHESON, John (1818) The Theory and Practice of Book-keeping.... Remarks on Bills and Promissory Bills; The Nature of Trade.... London.

MELLIS, John (1588) A Briefe Instruction and maner how to keepe bookes of Accomptes after the order of Debitor and Creditor, \& as well for proper Accompts partible, \& c. .... London: Iohn Windet.

MORRISON, James (1813) The Elements of Book-keeping by Single \& Double Entry. Comprising Several Sets of Books. Arranged According to Present Practice \& Designed for the Use of Schools. To Which is Annexed An Introduction on Merchants Accounts with Engraved Specimens. London: Longman, Hurst, Rees, Orme, Brown \& Green. 
[NORTH, Roger] (1714) The Gentleman Accomptant: or An Essay to Unfold the Mistery of Accompts. By Way of Debtor and Creditor, Commonly Called Merchants Accompts, and Applying the Same to the Concerns of the Nobility and Gentry of England... Done by a Person of Honour.... London: E. Curll.

PEELE, James (1553) The maner and fourme how to kepe a perfecte reconyng, after the order of the moste worthie and notable accompte of Debitour and Creditour.... London: Richard Grafton.

- [1569] The Pathe waye to perfectnes, in th'accomptes of Debitour, and Creditour: in manner of a Dialogue.... London: Thomas Purfoote.

Peragallo, Edward (1938) Origin and Evolution of Double Entry Bookkeeping. A Study of Italian Practice from the Fourteenth Century.... New York: American Institute Co.

PostLethwaYt, Malachy (1751) The Merchant's Public Counting-House: Or, New Mercantile Institution: Wherein is shewn, the Necessity of Young Merchants Being Bred to Trade with Greater Advantages than They Usually Are. With a Practicable Plan for That Purpose. Also Some Remarks on the Benefit of This Institution to the Young Nobility and Gentry, and Such Who Are Intended for the Study of the Law, Second Edition. London: John and Paul Knapton.

QUIN, M. (1776) Quin's Rudiments of Bookkeeping; Comprised in Six Plain Cases, and Attainable in as Many Days, Without the Help of a Teacher. Calculated for Persons of Either Sex, Grown to Maturity. With An Essay on the Fit Manner of Initiating Youth to Temperance and Moral Rectitude; By An Easy Arithmetical Scale. London: J. Bew.

ROE, R.B. (1825) An Introduction to Book-keeping... London.

SARLL, Andrew (1899) [1881] Double Entry Book-keeping in Theory and Practice; Illustrated by Short and Graduated Exercices; Followed by Examination Papers Arranged in Order of Their Difficulty.... London: George Gill \& Sons, Ltd.

SHERIFF, Daniel (1850) The Whole Science of Double-Entry Book-keeping, Simplified by the Introduction of an Unerring Rule for Debtor and Creditor, Calculated to Insure a Complete Knowledge of the Theory and Practice of Accounts. Designed for the Use of Merchants, Clerks, and Schools. London: J. Brown \& Co.

SNELL, Charles (1701) Rules for Book-keeping, According to the Italian Manner: Now in General Use. Directing Young Accomptants to the Books and Accompts, Where the Usual Occurrences in Trade Are to Be Enter'd; and in the Stile proper for such Entrances. London: John Place. 
SNELL, Charles (1718) The Merchants Counting-House: Or Wast-Book Instances, with Directions for Their Stating and Entrance.... London: Jonas Brown.

STEPHENS, Hustcraft (1735) Italian Book-keeping Reduced Into an Art: Being an Entire New and Compleat System of Accompts in General. Demonstrated in a Chain of Consequences from Clear and Self-Evident Principles. To Which is Added, The Greatest Variety of Merchants Accounts, with an Explanation of All the Terms of Art, Which have Commonly Been Madre Use of. Together with Proper Reflections on the Whole. London: W. Mears.

TAYLOR, William (1783) Complete System of Practical Arithmetic: With Various Branches in the Mathematics. Birmigham: Printed and Sold by the Author.

THORNTON, J. (1879) First Lessons in Book-keeping. London.

VAUTRO, P.C.L. (1828) A New System of Book Keeping; Calculated to Promote the Neccessary Reform of the Old Methods, by Following the Means Particularly Recommended by the Best english Authors. London.

VERNON, G.F. Carr (1893) Sets for Practice in Book-keeping. London: Charles Chappell.

W.P. (1596) The Pathway to Knowledge. Conteyning Certaine Briefe Tables of English Waights and Measures..., Written in Dutch and Translated into English by W.P.. London: William Barley.

WhITFIELD, E.E. (1900) Introduction to the Commercial Sciences. London: Rivingtons.

WICKS, J.H. (1797) Book-keeping Reformed.... Egham. 